Review Article

\title{
The Role of Descending Pain Modulation in Chronic Primary Pain: Potential Application of Drugs Targeting Serotonergic System
}

\author{
Zhuo-Ying Tao, ${ }^{1,2}$ Pei-Xing Wang, ${ }^{1}$ Si-Qi Wei, ${ }^{1}$ Richard J. Traub, ${ }^{3}$ Jin-Feng Li $\mathbb{D}^{2}{ }^{2}$ \\ and Dong-Yuan Cao ${ }^{1}{ }^{1}$ \\ ${ }^{1}$ Key Laboratory of Shaanxi Province for Craniofacial Precision Medicine Research, Research Center of Stomatology, Xi'an Jiaotong \\ University College of Stomatology, 98 West 5th Road, Xi'an, Shaanxi 710004, China \\ ${ }^{2}$ Department of Oral and Maxillofacial Surgery, Xi'an Jiaotong University College of Stomatology, 98 West 5th Road, Xi'an, \\ Shaanxi 710004, China \\ ${ }^{3}$ Department of Neural and Pain Sciences, School of Dentistry; Center to Advance Chronic Pain Research, University of \\ Maryland Baltimore, 650 W Baltimore St., Baltimore, MD 21201, USA
}

Correspondence should be addressed to Jin-Feng Li; 501367870@qq.com and Dong-Yuan Cao; dongyuan_cao@hotmail.com

Received 19 July 2019; Revised 2 November 2019; Accepted 27 November 2019; Published 17 December 2019

Academic Editor: Michael Borich

Copyright @ 2019 Zhuo-Ying Tao et al. This is an open access article distributed under the Creative Commons Attribution License, which permits unrestricted use, distribution, and reproduction in any medium, provided the original work is properly cited.

\begin{abstract}
Chronic primary pain (CPP) is a group of diseases with long-term pain and functional disorders but without structural or specific tissue pathologies. CPP is becoming a serious health problem in clinical practice due to the unknown cause of intractable pain and high cost of health care yet has not been satisfactorily addressed. During the past decades, a significant role for the descending pain modulation and alterations due to specific diseases of CPP has been emphasized. It has been widely established that central sensitization and alterations in neuroplasticity induced by the enhancement of descending pain facilitation and/or the impairment of descending pain inhibition can explain many chronic pain states including CPP. The descending serotonergic neurons in the raphe nuclei target receptors along the descending pain circuits and exert either pro- or antinociceptive effects in different pain conditions. In this review, we summarize the possible underlying descending pain regulation mechanisms in CPP and the role of serotonin, thus providing evidence for potential application of analgesic medications based on the serotonergic system in CPP patients.
\end{abstract}

\section{Introduction}

Chronic pain is a severe problem for the general population worldwide. Though pain itself does not cause death immediately, long-term suffering from pain exerts a negative impact on both work and living quality of patients. Some pain conditions are evoked by specific tissue damage which can be cured by cause-based treatment. However, others are absent of pathological alterations, such as fibromyalgia syndrome (FMS), irritable bowel syndrome (IBS), or temporomandibular disorder (TMD) $[1,2]$. During the past few decades, many different concepts have been used to describe these diseases, including functional somatic syndromes, somatoform pain disorders, and functional pain syndromes [3-5]. All these concepts regard "chronic pain" as a symptom only. Recently, the International Classification of Diseases-11 (ICD-11) has raised a new concept "chronic primary pain (CPP)" for these diseases, defining it as pain in one or more anatomical regions that (1) persists or recurs for over 3 months; (2) is associated with significant emotional distress or functional disability (interference with activities of daily life and participation in social roles); and (3) cannot be better accounted for by another chronic pain condition [6]. CPP includes a constellation of diseases with medically unexplained pain and disability which cause functional impairment or disruption of daily activities, namely, chronic widespread pain (e.g., FMS), complex regional pain syndromes, chronic primary headache and orofacial pain (e.g., chronic migraine 
or TMD), chronic primary visceral pain (e.g., IBS), and chronic primary musculoskeletal pain (e.g., nonspecific low back pain). This concept distinguishes functional pain without diagnostic laboratory tests or convincing medical explanations from pain secondary to underlying diseases. The most prominent progress of the new definition is that ICD-11 has incorporated "chronic pain" as a disease itself [7], which may contribute to the deeper understanding of pain pathophysiology and management.

CPP is a more severe problem in medical practice nowadays, not only because of its high prevalence (the general population prevalence for IBS is $11.2 \%$ [8], for FMS is $2.1 \%$ [9], and for TMD is $5-10 \%$ [10]) but also due to the high related consumption of health care resources [11, 12]. However, due to the lack of a definite pathology and the uncertainty of etiology and underlying mechanisms, the management of CPP is still poor. Patients often suffer from two or more diseases of CPP, resulting in comorbid or chronic overlapping pain conditions (COPC) $[13,14]$. Therefore, most patients seek treatment from physicians in different departments of hospitals, e.g., gastroenterologists, rheumatologists, dentists, neurologists, cardiologists, gynecologists, and otorhinolaryngologists. Eventually, patients do not receive fulfilling therapy, resulting in not only considerable cost in money and time but also intractable pain and anxiety. Hence, the development of new therapeutics for the pain management of CPP has become a critical need.

The descending pain system plays an important role in different pain conditions, and it is well recognized that descending control can be either facilitatory or inhibitory even though it cannot be fully dissociated anatomically [15]. The descending pain facilitatory system consists of the anterior cingulate cortex (ACC), the rostral ventromedial medulla (RVM), and the dorsal reticular nucleus of the medulla [16-18], while the descending inhibitory system includes the periaqueductal gray (PAG), RVM, and caudal lateral ventrolateral medulla (VLM) $[19,20]$. The descending control modulates pain circuitry at multiple levels, and numerous findings have identified that the imbalance of descending pain modulation favoring pain facilitation contributes to the promotion and maintenance of chronic pain [21].

The serotonergic system plays a critical role in the modulation of nociception mainly through descending pain circuits, during which neural plasticity changes between different regions of the brain [22]. Serotonin (5-hydroxytryptamine (5-HT)), an important neurotransmitter, exhibits its effect via activating different receptor subtypes [23, 24]. Besides 5-HT, some antidepressants, including tricyclic antidepressants (TCAs), selective serotonin reuptake inhibitors (SSRIs), and serotonin-norepinephrine reuptake inhibitors (SNRIs), can also exert an impact on pain perception through the 5-HT system [25]. In conditional knockout mice lacking central serotonergic neurons, SSRI-mediated analgesia was greatly reduced, suggesting the involvement of serotonergic neurons in the pain pathways [26]. Recently, studies on the effects of the descending pain system in CPP, such as IBS and FMS, have been performed, identifying the potential role of its therapeutic value $[27,28]$. Here, we review (1) the descending pain mechanisms mediated by the 5-HT system, focusing on CPP, including FMS, IBS, TMD, and chronic primary headache; (2) the clinical application of current and potential medicines targeting the serotonergic system in pain management; and (3) their prospects in CPP.

\section{Chronic Primary Pain}

2.1. Characteristics. Clinical studies indicate the diseases comprising CPP have many characteristics in common. First, chronic, diffuse, and intractable pain at different locations from head to limbs can be the most obvious symptom and it is always the main complaint of the patients. Second, functional disturbance in different organ systems (e.g., palpitation, dizziness, constipation or diarrhea, movement, insomnia, fatigue, or exhaustion) can be another frequent bodily complaint [29]. Third, CPP is more prevalent in women. Female patients are twice as likely to seek treatment for TMD and IBS compared to male patients [30, 31], and women outnumber men by an average of $3: 1$ in FMS patients from epidemiological studies [32]. Fourth, CPP patients are likely to have a history of physical or sexual abuse or childhood adversity, and the symptoms can be exacerbated by stress $[33,34]$. Fifth, these patients tend to suffer multiple conditions of CPP and overlap with psychiatric disorders such as anxiety and depression $[35,36]$.

CPP has a high prevalence worldwide, and the therapeutic treatment of CPP is unsatisfactory due to the unknown etiology. Both physicians and patients may feel confused about medically unexplained pain and are unfamiliar with how to give/obtain effective treatment since conventional medical therapy sometimes seems to be of no significant effect on these diseases. Some physicians even think the symptoms of CPP patients are less severe than they are reported when the symptoms cannot be well explained by contemporary medicine or definite pathology, leading to trust crises between physicians and patients [37]. Thus, CPP patients have more outpatient visits with associated expenditure on health care and are more likely to request/receive painkillers $[11,12]$.

\subsection{Possible Underlying Mechanism: Dysfunction of} Descending Pain Facilitatory and Inhibitory System. Two or more diseases of CPP tend to occur in one patient clinically. This may attribute to the consistent central mechanisms of CPP [7]. Therefore, the pain management of CPP may be similar. Although macroscopic peripheral damage is generally absent in CPP, there are some common pathophysiologic findings in the nervous system including abnormalities of the hypothalamus-pituitary-adrenal (HPA) axis, the autonomic nervous system, and sensory processing (central sensitization and a lack of descending inhibitory activity) [38-40]. In recent years, studies have identified an essential role of the descending pain modulation and its alterations in neuroplasticity in CPP. A systematic review on structural and functional brain magnetic resonance imaging (MRI) of FMS patients showed that the gray volume of the ACC decreased, but its functional activities increased and functional connectivity between brain regions in the descending pain 
inhibitory system decreased compared to healthy controls [41]. A clinical study found a correlation between decreased gut permeability and increased functional and structural connectivity of the right amygdala in moderate-to-severe IBS patients, while decreased gut permeability was associated with increased connectivity between the default mode network (DMN) and PAG in healthy controls [42]. Women with primary dysmenorrhea, a classified chronic pelvic pain syndrome, showed increased gray matter volume in the hypothalamus, hippocampus, PAG, and ACC [43], indicating reactive pain modulation. The high clinical overlap between painful TMD and headache disorders may attribute to the impairment of the descending inhibitory pain pathways [44]. These results suggest that the hyperactivity of descending pain facilitatory and/or the impairment of descending inhibitory system may contribute to CPP, providing a possible explanation of the overlap of pain in CPP patients and also a prospective therapeutic avenue for pain alleviation targeting the descending pain modulation.

\section{The Role of Serotonergic System in Descending Pain Modulation}

Maintaining a stable baseline of pain perception and processing can be attributed to the normal function of descending pain facilitatory and inhibitory systems. Abnormalities of these systems can lead to analgesia or hyperalgesia [45]. Many different neurotransmitters are involved in the occurrence and development of pain when disturbing this balanced state [46]. Among them, it has been well established that the descending serotonergic pathways can exert either a pronociceptive or antinociceptive impact, depending on different pain states and the multiplicity of subtype receptors activated [23, 47, 48]. 5-HT is widely distributed in different systems, including the nervous, gastrointestinal, and cardiovascular systems, and modulates a considerable collection of physiological and pathological conditions, including pain, sleep regulation, aggression, feeding, anxiety, and depression [49].

The abnormality of 5-HT signaling in different pain states has been identified in both basic research and clinical investigation and may be a possible and potential explanation for some diffuse pain states. In some neuropathic pain models, the baseline level of 5-HT in the spinal cord was decreased $[50,51]$, while in formalin or carrageenan inducedinflammatory pain models, the release of 5-HT in the dorsal raphe increased [52]. In FMS patients, the plasma 5-HT level decreased and its metabolite, 5-hydroxyindolacetic acid (5-HIAA) in the cerebrospinal fluid, also decreased [53]. These results demonstrate both a facilitatory role and an inhibitory role of 5-HT in the central nervous system (CNS), but the differences between these two opposing effects were not clear in these studies.

More recent studies focused on 5-HT receptor subtypes, which differ in structure, action, and localization in both the central and peripheral nervous systems. Most of these receptors are widely expressed in the spinal dorsal horn, where nociceptive information is relayed from primary afferent fibers and modulated by descending fibers prior to being transmitted to supraspinal sites [49]. Seven families of 5-HT receptors $\left(5-\mathrm{HT}_{1-7}\right)$ comprising 14 distinct receptor subtypes have been identified, including $5-\mathrm{HT}_{1 \mathrm{~A}-\mathrm{B}}, 5-\mathrm{HT}_{1 \mathrm{D}-\mathrm{F}}$, $5-\mathrm{HT}_{2 \mathrm{~A}-\mathrm{C}}, 5-\mathrm{HT}_{3}, 5-\mathrm{HT}_{4}, 5-\mathrm{HT}_{5 \mathrm{~A}-\mathrm{B}}, 5-\mathrm{HT}_{6}$, and $5-\mathrm{HT}_{7}[54]$. These receptors can be divided into two separate protein superfamilies: ligand-gated ion channel receptors $\left(5-\mathrm{HT}_{3}\right)$ and the $\mathrm{G}$ protein-coupled 7-transmembrane receptor superfamily (the rest of other 13 subtypes) [54]. With the synthesis and use of relatively selective agonists and antagonists for these subtypes, different animal models have been used to investigate the downstream effects of 5-HT/receptor signaling leading to effective or potential drugs in clinical application for numerous diseases including psychiatric disorders, pain conditions, gastrointestinal diseases, obesity, nausea, and vomiting. As for the function of $5-\mathrm{HT}$ receptors in descending pain modulation, the activation of the $5-\mathrm{HT}_{1 \mathrm{~A}}$, $5-\mathrm{HT}_{1 \mathrm{~B}}, 5-\mathrm{HT}_{1 \mathrm{D}}, 5-\mathrm{HT}_{5 \mathrm{~A}}$, and $5-\mathrm{HT}_{7}$ receptors is prone to exert an antinociceptive effect, whereas the $5-\mathrm{HT}_{2 \mathrm{~B}}$ and $5-\mathrm{HT}_{3}$ receptors tend to contribute to the promotion of nociception [23, 47, 48, 55-58]. However, there are still controversy and uncertainty over the role of these receptors in mediating nociceptive processing due to the location of the receptors, routes of drug administration, concentration and duration effects of agonists or antagonists, and even pain types in different studies [59]. In addition, some antidepressants like TCAs, SNRIs, and SSRIs can also influence the descending pain modulation system by increasing $5-\mathrm{HT}$ at the synaptic junction. The detailed function and present/future clinical application of 5-HT receptor agonists/antagonists and reuptake inhibitors affecting the serotonergic system in pain modulation will be reviewed and discussed below.

3.1. 5-HT Receptors. The 5- $\mathrm{HT}_{1}$ receptor family includes $5-\mathrm{HT}_{1 \mathrm{~A}}, 5-\mathrm{HT}_{1 \mathrm{~B}}, 5-\mathrm{HT}_{1 \mathrm{C}}, 5-\mathrm{HT}_{1 \mathrm{D}}, 5-\mathrm{HT}_{1 \mathrm{E}}$, and $5-\mathrm{HT}_{1 \mathrm{~F}}$ receptors [54]. After the $5-\mathrm{HT}_{1 \mathrm{C}}$ receptor was cloned and its characteristics identified, it was reclassified as a subtype of the $5-\mathrm{HT}_{2}$ receptor family, the $5-\mathrm{HT}_{2 \mathrm{C}}$ receptor [60].

The role of the $5-\mathrm{HT}_{1}$ receptor family except $5-\mathrm{HT}_{1 \mathrm{E}}$ in pain has been long studied both together and separately. Among them, the $5-\mathrm{HT}_{1 \mathrm{~A}}$ receptor has been extensively investigated for its analgesic effect in multiple pain states, including neuropathic, inflammatory, and visceral pain [61-63]. The activation of the $5-\mathrm{HT}_{1 \mathrm{~A}}$ receptor inhibits adenylyl cyclase thus reducing the intracellular concentration of cyclic adenosine monophosphate (cAMP), and subsequently, $\mathrm{K}^{+}$channels open and $\mathrm{Ca}^{2+}$ channels close, resulting in an inhibition of neuronal firing [64]. The analgesic effect of 5$\mathrm{HT}_{1 \mathrm{~A}}$ receptors has been widely recognized after 5- $\mathrm{HT}_{1 \mathrm{~A}}$ receptor-deficient (knockout) mice were established [65]. These mice have a higher nociceptive response in a hot plate test [65]. In the spinal cord, the activation of $5-\mathrm{HT}_{1 \mathrm{~A}}$ receptors can inhibit glutamate release, reinstate GABAdependent inhibition, and inhibit phosphorylation of $\mathrm{Ca}^{2+} /$ calmodulin-dependent protein kinase II (CaMKII) to reduce pain transmission [66-68]. Supraspinally, 5- $\mathrm{HT}_{1 \mathrm{~A}}$ receptors exert an antinociceptive impact via descending pain inhibitory pathway. $5-\mathrm{HT}_{1 \mathrm{~A}}$ receptors may contribute to inhibitory modulation of glutamate release in the ACC [69] and the 
inhibitory action of the GABAergic interneurons in the ventrolateral orbital cortex [70]. Glutamate administration in the central amygdala (CeA) produced bidirectional effects: increased hypersensitivity that was reversed by a spinal 5$\mathrm{HT}_{3}$ receptor antagonist and decreased hypersensitivity that was blocked by a spinal $5-\mathrm{HT}_{1 \mathrm{~A}}$ receptor antagonist, indicating a CeA-spinal descending pathway in pain modulation [71]. Somatosensory cortex (S2) stimulation caused antinociception in a spinal nerve ligation (SNL) model, and this effect was prevented by chemically activating $5-\mathrm{HT}_{1 \mathrm{~A}}$ receptors in the RVM or blocking $5-\mathrm{HT}_{1 \mathrm{~A}}$ receptors spinally, illustrating that S2 stimulation-induced analgesia in neuropathic pain is mediated by medullospinal descending serotonergic pathways [63]. In visceral pain, a clinical trial showed that tandospirone citrate (a partial agonist of $5-\mathrm{HT}_{1 \mathrm{~A}}$ receptors) had benefits in suppressing the abdominal symptoms of patients with functional dyspepsia [62], which was consistent with animal experiments [66]. Interestingly, in contrast to morphine, the analgesic effect associated with 5$\mathrm{HT}_{1 \mathrm{~A}}$ receptor agonists increases with repeated or chronic treatment $[72,73]$, suggesting a potential for their application in intractable pain management.

Because of the highly homologous structures, 5$\mathrm{HT}_{1 \mathrm{~B} / 1 \mathrm{D} / 1 \mathrm{~F}}$ receptors have similar functions in nociceptive information processing, especially in migraine. Triptans, the agonists of $5-\mathrm{HT}_{1 \mathrm{~B} / 1 \mathrm{D}}$ receptors, are the first-line acute therapy for patients who suffer from moderate-to-severe migraine attacks through acting on cerebral blood vessels to constrict vessels selectively and reduce neurogenic inflammatory mediators including calcitonin gene-related peptide [74]. Lasmiditan, a new selective $5-\mathrm{HT}_{1 \mathrm{~F}}$ receptor agonist and a promising drug in migraine, controls the symptoms via inhibiting dural plasma protein extravasation and decreasing c-Fos in the trigeminal nucleus caudalis without vasoconstrictive activities in peripheral tissues [75]. Some studies have identified the neural mechanisms of triptans in migraine besides vascular effects. Specifically, sumatriptan inhibited GABAergic and glutamatergic synaptic transmission through $5-\mathrm{HT}_{1 \mathrm{~B} / \mathrm{D}}$ receptors in the PAG [76], induced dose- and time-related blockade of visceral pain with intra-RVM administration [77], and reduced the release of glutamate presynaptically in the substantia gelatinosa of the spinal trigeminal nucleus pars caudalis [78], indicating that descending pain inhibitory system may be an additional potential site of action for the modulation of pain by $5-\mathrm{HT}_{1 \mathrm{~B} / 1 \mathrm{D}}$ receptors. Numerous behavioral or electrophysiological studies have already confirmed an analgesic role of the $5-\mathrm{HT}_{1 \mathrm{~B} / 1 \mathrm{D}}$ receptor at the spinal level $[79,80]$. A recent study focused on the downstream molecular mechanism of 5- $\mathrm{HT}_{1 \mathrm{~B}}$ receptors in the spinal cord. Specifically, 5- $\mathrm{HT}_{1 \mathrm{~B}}$ receptors activated phospholipase D1 which further activated phosphatidylinositol 4-phosphate (PIP) 5-kinase and PIP 2, leading to an allosteric enhancement of transient receptor potential melastatin 8 (TRPM8) [81]. However, there is no study on the PAG-RVM-spinal pathway or upstream mechanisms of these receptors. Further studies are needed to enrich the mechanism of $5-\mathrm{HT}_{1 \mathrm{~B} / 1 \mathrm{D}}$ receptors in descending inhibitory pain pathways, in order to support the application of $5-\mathrm{HT}_{1 \mathrm{~B} / 1 \mathrm{D}}$ receptor agonists in pain conditions.
3.2. $5-\mathrm{HT}_{2}$ Receptors. The $5-\mathrm{HT}_{2}$ receptor family contains three subtypes, $5-\mathrm{HT}_{2 \mathrm{~A}}$, $5-\mathrm{HT}_{2 \mathrm{~B}}$, and $5-\mathrm{HT}_{2 \mathrm{C}}$ receptors [49]. $5-\mathrm{HT}_{2 \mathrm{~A}}$ receptors are expressed in descending pain modulation pathways, including the nucleus raphe magnus (NRM), ventrolateral PAG (vlPAG), and the spinal dorsal horn, and also in reticular formation, thalamus, and limbic structures $[82,83]$. The distribution of $5-\mathrm{HT}_{2 \mathrm{~B}}$ receptors is restricted to a few brain regions, including the cerebellum, lateral septum, dorsal hypothalamus, medial amygdala, and spinal cord [54]. 5- $\mathrm{HT}_{2 \mathrm{C}}$ receptors are widely distributed in the locus coeruleus (LC), PAG, retrorubral area, substantia nigra pars compacta, ventral tegmental area, parabigeminal nucleus, basal nucleus, and laterodorsal tegmental nucleus [59].

Regarding the $5-\mathrm{HT}_{2}$ receptor family, most of the studies on pain modulation are focused on $5-\mathrm{HT}_{2 \mathrm{~A}}$ and $5-\mathrm{HT}_{2 \mathrm{C}}$ receptors, with minimal studies examining $5-\mathrm{HT}_{2 \mathrm{~B}}$ receptors. Furthermore, whether central $5-\mathrm{HT}_{2 \mathrm{~A} / 2 \mathrm{C}}$ receptors are pronociceptive or antinociceptive is controversial. In a recent study, blocking $5-\mathrm{HT}_{2 \mathrm{~A} / 2 \mathrm{C}}$ receptors in both the NRM and the gigantocellularis/paragigantocellularis pars reticular nuclei (Gi/PGi) reduced unconditioned fearinduced antinociception, suggesting that $5-\mathrm{HT}_{2 \mathrm{~A} / 2 \mathrm{C}}$ receptors in the Gi/PGi complex and NRM are critically recruited and participate in hypoalgesia during the panic-like emotional behavior [84]. Also, $5-\mathrm{HT}_{2 \mathrm{~A} / 2 \mathrm{C}}$ receptors in the dorsomedial PAG (dmPAG), vlPAG, dorsal raphe nucleus (DRN), and LC play a critical role in the elaboration of postictal antinociception [85-87]. However, a recent study found that increased expression of $5-\mathrm{HT}_{2 \mathrm{C}}$ receptors in nonGABAergic cells of the basolateral nucleus of amygdala (BLA) in rats with neuropathic pain and knockdown of $5-\mathrm{HT}_{2 \mathrm{C}}$ receptor in the BLA inhibited pain-related behaviors [88]. Another study reported that $5-\mathrm{HT}_{2 \mathrm{C}}$ in the amygdala reduced the effectiveness of SSRIs in inhibiting pain-related emotional-affective behaviors [89], indicating the participation of amygdala $5-\mathrm{HT}_{2 \mathrm{C}}$ receptors in pronociception. At the supraspinal level, $5-\mathrm{HT}_{2 \mathrm{~A} / 2 \mathrm{C}}$ receptors are more likely to contribute to antinociception, whereas they participate in either analgesia or hyperalgesia in the spinal cord from different reports. Activation of spinal $5-\mathrm{HT}_{2 \mathrm{~A} / 2 \mathrm{C}}$ receptors increased the pain-related behavioral responses in the early and late phases during formalin tests and also long-lasting hypersensitivity post formalin treatment $[90,91]$. But in spinal nerve injury models, intrathecal administration of $5-\mathrm{HT}_{2 \mathrm{~A}}$ or $5-\mathrm{HT}_{2 \mathrm{C}}$ receptor agonists produced antiallodynic effects [92, 93].

Further research has tried to investigate the contradictory results of $5-\mathrm{HT}_{2 \mathrm{~A}}$ receptors in pain modulation. A recent study found that the mechanical allodynia was related to sensitization, reduced dendritic arborization, and enhanced spine density exclusively in interneurons expressing the $\gamma$ isoform of protein kinase $\mathrm{C}\left(\mathrm{PKC} \gamma^{+}\right)$in a rat model of facial inflammatory pain. Blockade of $5 \mathrm{HT}_{2 \mathrm{~A}}$ receptors abolished the facial mechanical pain and related changes in the morphology of $\mathrm{PKC} \gamma^{+}$interneurons, suggesting that inflammation-induced pain contributes to morphological reorganization of $\mathrm{PKC} \gamma^{+}$ interneurons via $5-\mathrm{HT}_{2 \mathrm{~A}}$ receptor activation in pain circuitry [94]. Chemically activating $5-\mathrm{HT}_{2 \mathrm{~A}}$ receptors enhanced 
C-fiber-evoked dorsal horn potentials after SNL, which could be blocked by a metabotropic glutamate receptor 1 (mGluR1) antagonist, and $5-\mathrm{HT}_{2 \mathrm{~A}}$ receptors and mGluR1 were coexpressed in postsynaptic densities in dorsal horn neurons, confirming mGluR1 upregulation as a novel mechanism accounting for $5-\mathrm{HT}_{2 \mathrm{~A}}$ receptor-mediated pain facilitation [95]. However, an inhibitory role for $5-\mathrm{HT}_{2 \mathrm{~A}}$ receptors has also been identified. Activation of $5-\mathrm{HT}_{2 \mathrm{~A}}$ receptors hyperpolarized the reversal potential of inhibitory postsynaptic potentials (IPSPs), $\mathrm{E}_{\mathrm{IPSP}}$ in spinal motoneurons, activated PKC, and increased the cell membrane expression of neuron-specific $\mathrm{K}^{+}-\mathrm{Cl}^{-}$cotransporter (KCC2) after spinal cord injury in rats, indicating a PKC-dependent $5-\mathrm{HT}_{2 \mathrm{~A}}-\mathrm{KCC} 2$ pathway in neuropathic pain regulation [96]. Later, this pathway was confirmed to participate in other pain models, including thoracic hemisection, spared nerve injury, and incision pain [97, 98]. Another study showed that after activating $5-\mathrm{HT}_{2 \mathrm{~A}}$ receptors by intrathecal injection of a cell-penetrating peptidyl mimetic of the 5- $\mathrm{HT}_{2 \mathrm{~A}}$ receptor C-terminus (TAT-2ASCV), the interaction between $5-\mathrm{HT}_{2 \mathrm{~A}}$ receptors and postsynaptic density protein95 (PSD-95, one of the PSD-95/disc large suppressor/zonula occludens-1 domain containing proteins) was disrupted, followed by an anti-hyperalgesic effect in neuropathic pain of diabetic rats. Also, TAT-2ASCV enhanced SSRI-induced anti-hyperalgesia [99]. Recent studies identified this process in traumatic neuropathic pain and inflammatory pain models $[100,101]$, as well as the evidence that spinal GABA release and $\mathrm{GABA}_{\mathrm{A}}$ receptor activation are involved in this process [101, 102]. Presently, a final conclusion of the facilitatory or inhibitory role of $5-\mathrm{HT}_{2 \mathrm{~A} / 2 \mathrm{C}}$ receptors in painrelated circuits in the descending pain system is still not clear. Though some medications targeting $5-\mathrm{HT}_{2 \mathrm{~A} / 2 \mathrm{C}}$ receptor subtypes have been applied in clinical practice, including blonanserin $\left(5-\mathrm{HT}_{2 \mathrm{~A}}\right.$ receptor antagonist) in schizophrenia [103] and lorcaserin $\left(5-\mathrm{HT}_{2 \mathrm{c}}\right.$ receptor agonist) in obesity [104], more studies are needed to figure out the function and mechanism of $5-\mathrm{HT}_{2 \mathrm{~A} / 2 \mathrm{C}}$ receptors in the descending pain modulation pathway.

As for $5-\mathrm{HT}_{2 \mathrm{~B}}$ receptors, limited studies have identified a pronociceptive role in pain control, supporting the prospect of $5-\mathrm{HT}_{2 \mathrm{~B}}$ receptor antagonists as painkillers in the future. In a SNL model, $5-\mathrm{HT}_{2 \mathrm{~B}}$ receptor expression increased in the ipsilateral dorsal spinal cord and dorsal root ganglia (DRG), and intrathecal administration of the $5-\mathrm{HT}_{2 \mathrm{~B}}$ receptor antagonist diminished both allodynia and $5-\mathrm{HT}_{2 \mathrm{~B}}$ expression after nerve injury [105]. Another study confirmed that $5-\mathrm{HT}_{2 \mathrm{~B}}$ receptor-mediated facilitation in neuropathic pain may contribute to the transient activation of the PKC $\gamma / \mathrm{NMDA}$ receptor pathway [106]. In visceral hypersensitive Wistar Kyoto rats, both peripheral and intracerebroventricular injection of RS-127445 $\left(5-\mathrm{HT}_{2 \mathrm{~B}}\right.$ receptor antagonist) reduced pain behaviors during noxious colorectal distension, providing a possible target for pain relief in gastrointestinal disorders such as IBS [107]. However, the present studies on $5-\mathrm{HT}_{2 \mathrm{~B}}$ receptor antagonists in pain alleviation are not yet adequate to organize preclinical or clinical studies investigating the efficacy and safety in human beings.
3.3. $5-\mathrm{HT}_{3}$ Receptors. The $5-\mathrm{HT}_{3}$ receptor is the only ligand-gated ion channel among all 5-HT receptor subtypes [54]. 5- $\mathrm{HT}_{3}$ receptor has two subunits $\left(5-\mathrm{HT}_{3 \mathrm{~A}}\right.$ and $\left.5-\mathrm{HT}_{3 \mathrm{~B}}\right)$ in rodents $[108]$ and five subunits $\left(5-\mathrm{HT}_{3 \mathrm{~A}-\mathrm{E}}\right)$ in human beings [109]. In the nervous system, functional $5-\mathrm{HT}_{3}$ receptors can be formed from either five $5-\mathrm{HT}_{3 \mathrm{~A}}$ subunits (homopentameric) or a mixture of $5-\mathrm{HT}_{3 \mathrm{~A}}$ and one of the other four receptor subunits (heteropentameric) [110]. $5-\mathrm{HT}_{3}$ receptors are highly expressed in the dorsal vagal complex of the brainstem, hippocampus, amygdala, superficial layers of the cerebral cortex, and spinal dorsal horn [54].

The role of $5-\mathrm{HT}_{3}$ receptors in nociceptive processing in the descending pain pathway has been widely investigated through 5- $\mathrm{HT}_{3}$ receptor agonists (e.g., SR57227, YM-31636, and $\mathrm{mCPBG}$ ) and antagonists (e.g., Y25130, granisetron, ondansetron, ramosetron, palonosetron, dolasetron, and tropisetron). Though there are some early studies which reported antinociceptive effects of $5-\mathrm{HT}_{3}$ receptors $[111,112]$, it is now well recognized that $5-\mathrm{HT}_{3}$ receptors play an important role in the descending pain facilitatory system based on the genetic studies clarifying that $5-\mathrm{HT}_{3}$ receptors are involved in persistent, but not acute, pain. Specifically, in $5-\mathrm{HT}_{3}$ knockout mice, a significant reduction of the second phase, but not the first phase, of pain behavior in the formalin test was reported compared to wild-type mice $[65,113]$. Also, $5-\mathrm{HT}_{3}$ receptors had no effect on acute pain produced by physiologically relevant stimuli and an antagonist did not change nociceptive thresholds when it was administered alone in wild-type mice without tissue injuries [113]. Recently, electrophysiological, molecular, biological, and behavioral studies have confirmed that the activation of $5-\mathrm{HT}_{3}$ receptors in the spinal cord is involved in persistent pain, including chronic inflammatory pain [55], postoperative pain [17], visceral hypersensitivity [114], neuropathic pain [115], cancer pain [116], and opioid-induced hyperalgesia [117]. Specifically, systemic administration of the serotonin precursor producing visceral hypersensitivity and somatic analgesia could be attenuated by intrathecal treatment of ondansetron (5- $\mathrm{HT}_{3}$ receptor antagonist) [118], and spinal injection of ondansetron also exerted an analgesic impact in animal models of spinal nerve injury, cancerinduced bone pain, osteoarthritis, and hyperalgesia induced by morphine treatment $[55,115-117]$.

In addition to $5-\mathrm{HT}_{3}$ receptors and spinal modulation of pain, the role of supraspinal regions modulating spinal $5-\mathrm{HT}_{3}$ receptors have been examined. For example, intrathecal injection of ondansetron can reverse the mechanical hypersensitivity induced by low-dose administration of glutamate in the CeA [71]. Thermal hyperalgesia and tactile allodynia induced by microinjection of cholecystokinin (CCK) in RVM are attenuated by spinal administration of ondansetron [47], indicating descending control from the amygdala and $\mathrm{RVM}$ to facilitate pain via activating $5-\mathrm{HT}_{3}$ receptors in the spinal cord. In a chronic postoperative pain model, increased 5-HT release and $5-\mathrm{HT}_{3}$ receptor expression and activation of microglia were found in the L3 spinal dorsal horn. Intrathecal injection of Y-25130 could block pain behaviors and molecular changes. Meanwhile, in the RVM, $\mathrm{P}_{2} \mathrm{X}_{7}$ receptors on microglia were upregulated, 
microglia were activated, and 5-HT release increased. Microinjection of a $\mathrm{P}_{2} \mathrm{X}_{7}$ receptor antagonist into $\mathrm{RVM}$ reversed the pain behaviors and molecular changes as well. These results have suggested that $\mathrm{P}_{2} \mathrm{X}_{7}$ receptor activation in microglia in the RVM contributes to the enhancement of the RVM-spinal 5-HT system through actions of 5- $\mathrm{HT}_{3}$ receptors and hyperactivity of microglia at the spinal level [17]. Another study investigated the neuron-microgliaastrocyte-neuron circuit after activating $5-\mathrm{HT}_{3}$ receptors in the spinal cord, explaining the interactions between 5$\mathrm{HT}_{3}$ receptors and microglial activity in pain processing [119]. Specifically, intrathecal administration of the $5-\mathrm{HT}_{3}$ receptor agonist SR57227 induced selective activation of 5$\mathrm{HT}_{3}$ receptors in neurons which released the neuroactive substance fractalkine targeting its receptors on microglia. The activated microglia upregulated and released interleukin- (IL-) 18 to activate astrocytes which released IL-1 $\beta$ [119]. IL-1 $\beta$ combined with its receptors colocalized with glutamate receptor NMDA type subunit 1 (GluN1) receptors on the dorsal horn neurons increasing phosphorylation of GluN1 receptors [119]. All these molecular changes could be abolished by the depletion of the 5-HT in RVM; thus, the $5-\mathrm{HT}_{3}$ receptor (neuron)-fractalkine (neuron)-IL18 (microglia)-IL1 $\beta$ (astrocytes)-GluN1 receptor (neuron) signaling pathway in dorsal horn might be the downstream mechanism of the descending pain facilitatory system [119].

Therefore, $5-\mathrm{HT}_{3}$ receptors are important contributors to the production and maintenance of persistent pain via the central mechanisms in the descending pain facilitatory system. To date, randomized controlled studies have found that $5-\mathrm{HT}_{3}$ receptor antagonist ramosetron can improve stool consistency, relieve abdominal pain/discomfort, and promote health-related quality of life in IBS patients [120-122], possibly based on a peripheral mechanism that blockade of $5-\mathrm{HT}_{3}$ receptors in the gastrointestinal system ameliorates colonic transit rates [123]. Repeated tender point injections of $5-\mathrm{HT}_{3}$ antagonist granisetron alleviated chronic myofascial pain in TMD patients [124]. 5- $\mathrm{HT}_{3}$ receptor antagonists dolasetron and tropisetron have been assessed for efficacy in FMS patients [125, 126]. Our recent studies also provided evidence for $5-\mathrm{HT}_{3}$ receptors involved in somatic pain, an obvious symptom of FMS [127]. Specifically, we established an FMS model with three-day forced swim stress in female rats and investigated the role of the spinal $5-\mathrm{HT}_{3}$ receptors in somatic pain induced by stress [127]. We found that the expression of $5-\mathrm{HT}_{3}$ receptors in L4-5 spinal dorsal horn upregulated with the occurrence of pain and blocking $5-\mathrm{HT}_{3}$ receptors by intrathecal administration of Y25130 reversed this process, providing a possible mechanism of $5-\mathrm{HT}_{3}$ receptor antagonists applied in chronic pain without local tissue pathology [127]. As $5-\mathrm{HT}_{3}$ receptor antagonists are rapidly absorbed and easily penetrate the blood-brain barrier [128], these drugs may control pain in IBS, TMD, and FMS through the central mechanisms combined with their peripheral functions, leading to a hypothesis that $5-\mathrm{HT}_{3}$ receptor antagonists can be candidate drugs in chronic pain management of patients with CPP.
3.4. 5- $\mathrm{HT}_{4}$ Receptors. $5-\mathrm{HT}_{4}$ receptors are $\mathrm{G}$ protein-coupled receptors which are widely expressed in the spinal cord, whole brain, and gut $[129,130] .5-\mathrm{HT}_{4}$ receptor agonists (cisapride, mosapride, tegaserod, and prucalopride) have been widely used in IBS patients with constipation as a prokinetic medicine, mainly because of a local mechanism that presynaptic $5-\mathrm{HT}_{4}$ receptors expressed in the myenteric plexus can increase peristaltic reflex activity by releasing more acetylcholine [131]. Recently, $5-\mathrm{HT}_{4}$ receptor agonists have been identified with good efficacy in abdominal pain attenuation possibly based on a central mechanism. It has been found that tegaserod could reduce the rectal sensitivity to distension significantly in IBS patients [132] and the responses to nociceptive stimulation of intestine in animal models of visceral pain [133]. The analgesic effects of $5 \mathrm{HT}_{4}$ receptor agonists may relate to their action at a supraspinal level $[20,133]$. Specifically, intravenous administration of $5-\mathrm{HT}_{4}$ receptor agonists produced dose-dependent suppression of the visceromotor response (an objective measure of visceral sensation) and the activity of caudal ventrolateral medullary (CVLM) neurons, which could be blocked by intracerebroventricular pretreatment with $5-\mathrm{HT}_{4}$ receptor antagonist [20], indicating the preferential involvement of supraspinal $5-\mathrm{HT}_{4}$ receptors. Microinjection of tegaserod into the RVM, but not the spinal cord, attenuated the visceromotor response and reduced the spontaneous firing of lumbosacral neurons. These actions could be blocked by an intra-RVM injection of an opioid receptor antagonist or $5-\mathrm{HT}_{4}$ receptor antagonist or intrathecal injection of an $\alpha 2$-adrenergic receptor antagonist, indicating that $5-\mathrm{HT}_{4}$ receptors play an analgesic role through the opioidergic system in the RVM and descending noradrenergic pathways, and are excluded from the direct mechanisms at the spinal level [133]. Another study reported that intrathecal blockade of $5-\mathrm{HT}_{4}$ receptors could reverse 5-HT-induced inhibition of $\mathrm{C}$ fiber-evoked responses on wide dynamic range neurons [134], suggesting that the spinal $5-\mathrm{HT}_{4}$ receptors act in an antinociceptive role. However, in the formalin test, the activation of $5-\mathrm{HT}_{4}$ receptors in the spinal cord exerted a pronociceptive effect on secondary mechanical allodynia and hyperalgesia [135]. Therefore, the facilitatory or inhibitory role of $5-\mathrm{HT}_{4}$ receptors and the location in the descending pain system where they function remain to be determined. Despite the clinical application of $5-\mathrm{HT}_{4}$ receptor agonists in IBS patients, the antinociceptive mechanism needs further studies.

3.5. 5- $\mathrm{HT}_{5}$ Receptors. The $5-\mathrm{HT}_{5}$ receptor might be the least studied among 5-HT receptors, and very little has been learned about the functions of it. $5-\mathrm{HT}_{5 \mathrm{~A}}$ and $5-\mathrm{HT}_{5 \mathrm{~B}}$ receptors are two different subtypes which have been identified in rodents $[136,137]$, but in humans, only the $5-\mathrm{HT}_{5 \mathrm{~A}}$ receptor is functional. The human $5-\mathrm{HT}_{5 \mathrm{~B}}$ gene is interrupted by stop codons and transcribed and translated into nonfunctional protein [138]. Therefore, here, we only discuss $5-\mathrm{HT}_{5 \mathrm{~A}}$ receptors. $5-\mathrm{HT}_{5 \mathrm{~A}}$ receptors are highly expressed in superficial layers of the dorsal horn, lumbar dorsolateral nucleus, raphe nuclei, and higher brain areas, such as the cerebral cortex and hippocampus [139], relating to their function in 
psychiatric disorders (schizophrenia, bipolar disorder, anxiety, and depression) [140], memory and cognition [141], obesity [142], and pain processing [143]. To date, no $5-\mathrm{HT}_{5 \mathrm{~A}}$ receptor ligands have been applied to clinical practice though some selective agonists (valerenic, 5-carboxamidotryptamine) and antagonists (SB-699551) have been synthesized.

In recent years, a few studies have identified the antinociceptive role of the activation of $5-\mathrm{HT}_{5 \mathrm{~A}}$ receptors at the spinal level. Inspired by Doly et al.'s hypothesis that $5-\mathrm{HT}_{5 \mathrm{~A}}$ receptors play an analgesic role according to their distribution in the superficial layers of the spinal dorsal horn [139], Munoz-Islas and colleagues investigated their function in the formalin, capsaicin, and acetic acid writhing tests. They concluded that the antinociceptive effect induced by intrathecal injection of 5-HT or 5-carboxamidotryptamine is attributed to the activation of spinal $5-\mathrm{HT}_{5 \mathrm{~A}}$ receptors in both the spinal cord and DRG [143]. It has been shown that $5-\mathrm{HT}_{5 \mathrm{~A}}$ receptors play an analgesic role in neuropathic pain [79] and inflammatory pain [144] and contribute to antinociceptive effects of cannabinoid receptors and morphine [58]. Thus, $5-\mathrm{HT}_{5 \mathrm{~A}}$ receptor agonists might be a potential drug in pain relief, but further studies should be performed to examine the inhibitory function and molecular mechanisms of 5- $\mathrm{HT}_{5 \mathrm{~A}}$ receptors in supraspinal level of descending pain modulation system.

3.6. $5-\mathrm{HT}_{6}$ Receptors. After the $5-\mathrm{HT}_{6}$ receptor was initially discovered as a novel 5-HT-sensitive receptor and its cDNA sequence identified in 1993 [145], few studies have been performed investigating its role in pain modulation. $5-\mathrm{HT}_{6}$ receptors are located in the spinal cord, on GABAergic neurons of the striatum, olfactory tubercle and nucleus accumbens, and glutamatergic neurons of the hippocampus and cortex $[146,147]$. Oral administration of $5-\mathrm{HT}_{6}$ receptor antagonists had an antinociceptive effect in neuropathic pain either on their own or cooperating with gabapentinoids $[148,149]$. Spinal injection of $5-\mathrm{HT}_{6}$ receptor agonists could facilitate pain behaviors in the formalin test [150], while intrathecal treatment with $5-\mathrm{HT}_{6}$ receptor antagonists decreased tactile allodynia in neuropathic pain [146]. At the supraspinal level, the activation of $5-\mathrm{HT}_{6}$ receptors seems to inhibit pain, since in the DRN $5-\mathrm{HT}_{6}$ receptors participated in the postictal antinociception elicited by tonic-clonic seizures [151]. However, none of study focuses on cellular or molecular mechanisms, thus why $5-\mathrm{HT}_{6}$ receptors function differently in different parts of the nervous system needs further investigations.

3.7. $5-\mathrm{HT}_{7}$ Receptors. The $5-\mathrm{HT}_{7}$ receptor family is the most recently identified member of 5-HT receptors [152]. Up to date, there are three functional $5-\mathrm{HT}_{7}$ subtypes in humans including $5-\mathrm{HT}_{7 \mathrm{~A}}, 5-\mathrm{HT}_{7 \mathrm{~B}}$, and $5-\mathrm{HT}_{7 \mathrm{D}}[153] .5-\mathrm{HT}_{7}$ receptors are expressed in the periphery and CNS of different species, including the thalamus, hypothalamus, hippocampus, striatum, cortex, and spinal dorsal horn [154]. The role of $5-\mathrm{HT}_{7}$ receptors in the pain processing has been extensively studied using agonists (e.g., AS-19, LP-211, MSD-5a, and E-55888) and antagonists (e.g., SB-269970 and SB-25719). $5-\mathrm{HT}_{7}$ receptors have been widely recognized to play a significant role in analgesia at the spinal level $[155,156]$, consistent with the immunocytochemical localization in the superficial dorsal horn and in small and medium-sized DRG cells [157]. The analgesic effect of $5-\mathrm{HT}_{7}$ receptor agonists was blocked by $\mathrm{GABA}_{\mathrm{A}}$ antagonists, but not $\mathrm{GABA}_{\mathrm{B}}$ or opioid receptor antagonists [158], and $5-\mathrm{HT}_{7}$ receptors colocalized with GABAergic cells in the dorsal horn of the spinal cord in rats with nerve injury [159], suggesting the activation of GABAergic inhibitory interneurons may account for the analgesic role of $5-\mathrm{HT}_{7}$ receptors in pain processing. The blockade of $5-\mathrm{HT}_{7}$ receptors reduced the antiallodynic effect of intrathecal nefopam (a nonopioid analgesic drug) or SSRIs in neuropathic pain models and abolished systemic tramadol or paracetamol-induced antinociceptive and antihyperalgesic effects, leading to an assumption that the spinal $5-\mathrm{HT}_{7}$ receptor is a contributor in the antiallodynic efficacy of these analgesics, possibly via activating the descending serotonergic pathway and spinal $5-\mathrm{HT}_{7}$ receptors [160, 161]. However, there are still some controversial results. In a neuropathic pain model, the expression of the $5-\mathrm{HT}_{7}$ receptors in the spinal cord decreased and the $5-\mathrm{HT}_{7}$ receptor antagonist SB-269970 evoked an analgesic effect in a dosedependent manner in rats [162]. Although intrathecal AS19 (agonist) reversed the increase of pain behaviors in the formalin test, neither AS-19 nor SB-269970 (antagonist) had an anti- or pronociceptive effect on carrageenaninduced mechanical allodynia [163]. These conflicting results of $5-\mathrm{HT}_{7}$ receptors in the spinal cord may attribute to the use of different animal species, pain models, ligands, and detection methods.

It has been observed that $5-\mathrm{HT}_{7}$ receptors play an antinociceptive role in the modulation of signals along the descending pain pathway from the supraspinal level. Spinal administration of $5-\mathrm{HT}_{7}$ receptor antagonist SB-269970 blocked the antinociceptive effects of intra-RVM morphine treatment, suggesting that the descending pain inhibitory pathway from RVM act ultimately in the spinal cord in pain states through the activation of $5-\mathrm{HT}_{7}$ receptors [47]. In a neuropathic pain model induced by chronic constriction injury of the sciatic nerve, the expression of $5-\mathrm{HT}_{7}$ receptors in vlPAG increased, and intra-vlPAG administration of $5-\mathrm{HT}_{7}$ receptor agonist AS-19 significantly and dosedependently attenuated mechanical pain [19]. The antihyperalgesic effect of AS-19 could be prevented by pretreatment of SB-269970 and partially blocked by A-317491 (a $\mathrm{P}_{2} \mathrm{X}_{3}$ receptor antagonist), indicating that the 5- $\mathrm{HT}_{7}$ receptors interacting with $\mathrm{P}_{2} \mathrm{X}_{3}$ receptors in the vlPAG exhibit an analgesic action through the enhancement of descending pain inhibitory system [19]. Acute injection of LP-211 (a new 5- $\mathrm{HT}_{7}$ receptor agonist which can penetrate the blood-brain barrier) had an analgesic effect in neuropathic pain animals, which was partially mediated by an action in the ACC by targeting hyperpolarization-activated cyclic nucleotide- (HCN-) gated channels in the apical dendrites on layer 5 pyramidal cells [164]. From these studies, we can conclude that $5-\mathrm{HT}_{7}$ receptors present and function along the ACC-PAG-RVM-spinal cord pathway and exert an antinociceptive effect through the descending inhibitory system; therefore, some brain-penetrant $5-\mathrm{HT}_{7}$ receptor 
agonists can be potential candidate painkillers for pain management in the future.

The function of $5-\mathrm{HT}_{7}$ receptors in $\mathrm{CPP}$ has been identified recently. In a morphological study, the protein level of $5-\mathrm{HT}_{7}$ receptors in both the brain (hippocampus and hypothalamus) and the gut (ileum and colon) was notably higher in rats with the IBS model compared with the controls, illustrating that upregulation of $5-\mathrm{HT}_{7}$ receptors in the brain and gut contributes to the pathogenesis of IBS [165]. A recent study performed on both animal models and human volunteers has confirmed the role of $5-\mathrm{HT}_{7}$ receptors in IBS, showing that intestinal tissues of IBS patients and mice had higher levels of miRNA-29a but had lower levels of $5-\mathrm{HT}_{7}$ receptors, and miRNA-29a knockout leads to overexpression of $5-\mathrm{HT}_{7}$ receptors and attenuation in visceral hyperalgesia in IBS mice [166]. Though these two studies provide evidence of $5-\mathrm{HT}_{7}$ receptors functioning in IBS both peripherally and centrally, the application of $5-\mathrm{HT}_{7}$ receptor agonists in treating IBS or other CPP diseases still needs further investigations.

3.8. Antidepressants Affecting Serotonergic System. The commonly prescribed antidepressants affecting the serotonergic system are TCAs (e.g., desipramine, trimipramine, tianeptine, amitriptyline, doxepin, clomipramine, and imipramine), SSRIs (e.g., fluoxetine, paroxetine, citalopram, escitalopram, sertraline, and fluvoxamine), and SNRIs (e.g., venlafaxine, duloxetine, and milnacipran) [167]. The analgesic effect of these antidepressants has been long studied. The theory is that these drugs inhibit the reuptake of 5-HT and/or noradrenaline into neuronal terminals, thus leading to the accumulation of these neurotransmitters at the synaptic junction and the enhancement of pain suppression via multiple postsynaptic receptor-mediated mechanisms and the descending pain inhibitory tracts [168-170]. Among these drugs, TCAs seem to have stronger pain-relieving efficacy than SSRIs and SNRIs. For example, TCAs relieve pain in one in every $2-3$ patients with neuropathic pain, while SNRIs and SSRIs are effective in one in every $4-5$ and one in every 7 patients, respectively [171]. However, with lower efficacy in relieving pain, SSRIs are better tolerated and have less incidence of side effects [167]. As for CPP, these antidepressants have been examined for their efficacy in FMS, IBS, chronic headache, and low back pain.

A meta-analysis focusing on the treatment of FMS with antidepressants has shown that TCAs hold larger effect sizes for pain reduction than SSRIs [172]. The efficacy of TCAs in both pain and other symptoms (fatigue, insomnia, stiffness, and tenderness) of FMS has been well established by multiple studies, and TCAs are the first-line medication for FMS treatment [173]. Amitriptyline (10-75 mg/day) is the most frequent choice because it clinically reduces pain and sleep disturbances and its risk tolerability and safety issues at this dose are low (much lower than that in depression treatment) [174]. As for SNRIs and SSRIs, there are some positive results applied in FMS. For example, duloxetine $(60-120 \mathrm{mg} / \mathrm{d}) \mathrm{had}$ a positive effect in FMS though a greater improvement in mental symptoms rather than somatic pain may attribute to it [175]. Fluoxetine was more effective on key symptoms than placebos with good tolerability in female FMS patients at a flexible dose $(45 \pm 25 \mathrm{mg} / \mathrm{d})$ [176], and it worked better in combination with amitriptyline $(20 \mathrm{mg}$ fluoxetine in the morning and $25 \mathrm{mg}$ amitriptyline at bedtime) [177]. However, two recent systematic reviews have shown no strong evidence supporting SNRIs and SSRIs as superior to placebo in either pain or health-related quality of life $[178,179]$.

Similar results for IBS in terms of the efficacy of antidepressants were reported. According to evidence-based studies, TCAs provided increased benefit for alleviating abdominal pain and improving the quality of life compared with placebo [180, 181]. Low-dose TCAs (e.g., $25 \mathrm{mg}-75 \mathrm{mg} / \mathrm{d}$ of amitriptyline and $75 \mathrm{mg} / \mathrm{d}$ of doxepin) treatment for 1-3 months exhibited clinically significant control of IBS [182]. However, the effectiveness of SSRIs for the treatment of IBS remains controversial $[180,181,183]$. For example, six weeks of treatment with citalopram $(20 \mathrm{mg} / \mathrm{d}$ for 3 weeks and $40 \mathrm{mg} / \mathrm{d}$ for the following 3 weeks) significantly suppressed IBS symptoms independent of effects on psychiatric disorders and colonic sensorimotor function in a Belgian study [184], but eight-week citalopram treatment $(20 \mathrm{mg} / \mathrm{d}$ for 4 weeks and then $40 \mathrm{mg} / \mathrm{d}$ for 4 weeks) did not show superiority compared to placebo in treating nondepressed IBS patients in another study in the US [185]. As for SNRIs, several open-label pilot studies suggested that short-term duloxetine (dose ranges from 20 to $120 \mathrm{mg} / \mathrm{d}$ ) is beneficial for IBS comorbid with/without depression or anxiety [186-188].

In chronic headache, a meta-analysis has illustrated that TCAs are modestly effective in relieving chronic tensiontype headache [189]. Amitriptyline $(25-75 \mathrm{mg} / \mathrm{d})$ decreased headache frequency intensity and increased health-related quality of life in chronic tension headache [190], and it has been recommended as the first choice for the prophylactic treatment of this disease by the European Federation of Neurological Societies [191]. However, SSRIs and SNRIs are not supported by the evidence for the prevention of either chronic tension headache or migraine $[192,193]$. As for low back pain, duloxetine $(60 \mathrm{mg} / \mathrm{d}$ for about 3 months) lowered pain intensity modestly [194] but neither TCAs nor SSRIs are more effective than placebo based on previous studies [195].

We can summarize from the studies above that there is inconsistency between the efficacy of different antidepressants and different CPP conditions. In most cases, TCAs showed better results and are better choices for CPP though the side effects and adverse events always contribute to the participants' withdrawal from trials [167]. Without strong evidence in previous clinical practice, SNRIs and SSRIs should only be encouraged to apply in patients with CPP who have failed to have response to conventional therapies of TCAs or comorbid with psychiatric disorders. Still, further clinical trials with a good methodology and larger sample sizes are needed to lower the risk of bias for antidepressants.

\section{Conclusion}

Central sensitization induced by the imbalance of descending pain facilitation and inhibition systems might be a rational explanation of pain processing and comorbidities in CPP 
based on both experimental and clinical evidence. Treating pain as a disease rather than an individual symptom is a trend after deeper and further understanding of pathologies in the CNS. After reviewing all the studies above focusing on the role of serotonergic system in pain processing, especially in specific diseases of CPP, we conclude that either drugs targeting 5-HT receptors or antidepressants that enhance 5-HT signaling lead to a prospect of painkillers targeting this system in patients with CPP in future clinical practice. TCAs can be a good choice for several diseases of CPP including FMS, IBS, and chronic headache based on clinical evidence. The agonists of $5-\mathrm{HT}_{1 \mathrm{~A}}$, $5-\mathrm{HT}_{1 \mathrm{~B} / 1 \mathrm{D}}, 5-\mathrm{HT}_{4}, 5-\mathrm{HT}_{5 \mathrm{~A}}$, and $5-\mathrm{HT}_{7}$ and the antagonists of $5-\mathrm{HT}_{3}$ might be potential candidates of analgesic medications for CPP patients. In spite of the fact all the ligands of the above receptors have been well synthesized and examined in animal experiments, some even in humans, further investigations of their molecular mechanisms, role in the descending pain modulation system, side effects, administration methods, and effective dose and efficacy in CPP are necessary in order to provide reliable evidence for future clinical application.

\section{Conflicts of Interest}

The authors declare that there is no conflict of interest regarding the publication of this article.

\section{Acknowledgments}

This work was supported by the National Natural Science Foundation of China (Nos. 81971049 and 81671097) and partially by the open funds of the State Key Laboratory of Medical Neurobiology of China.

\section{References}

[1] W. Hauser, J. Ablin, M. A. Fitzcharles et al., "Fibromyalgia," Nature Reviews Disease Primers, vol. 1, no. 1, p. 15022, 2015.

[2] P. Enck, Q. Aziz, G. Barbara et al., "Irritable bowel syndrome," Nature Reviews Disease Primers, vol. 2, no. 1, article 16014, 2016.

[3] S. Wessely, C. Nimnuan, and M. Sharpe, "Functional somatic syndromes: one or many?," The Lancet, vol. 354, no. 9182, pp. 936-939, 1999.

[4] N. Egloff, R. J. Camara, R. von Kanel, N. Klingler, E. Marti, and M. L. Ferrari, "Hypersensitivity and hyperalgesia in somatoform pain disorders," General Hospital Psychiatry, vol. 36, no. 3, pp. 284-290, 2014.

[5] F. Perry, P. H. Heller, and J. D. Levine, "A possible indicator of functional pain: poor pain scale correlation," Pain, vol. 46, no. 2, pp. 191-193, 1991.

[6] B. H. Smith, E. A. Fors, B. Korwisi et al., "The IASP classification of chronic pain for ICD-11: applicability in primary care," Pain, vol. 160, no. 1, pp. 83-87, 2019.

[7] R. D. Treede, W. Rief, A. Barke et al., "A classification of chronic pain for ICD-11," Pain, vol. 156, no. 6, pp. 10031007, 2015.

[8] R. M. Lovell and A. C. Ford, "Global prevalence of and risk factors for irritable bowel syndrome: a meta- analysis,"
Clinical Gastroenterology and Hepatology, vol. 10, no. 7, pp. 712-721.e4, 2012.

[9] A. Cabo-Meseguer, G. Cerda-Olmedo, and J. L. Trillo-Mata, "Fibromyalgia: prevalence, epidemiologic profiles and economic costs," Medicina Clínica, vol. 149, no. 10, pp. 441-448, 2017.

[10] V. E. Miller, C. Poole, Y. Golightly et al., "Characteristics associated with high-impact pain in people with temporomandibular disorder: a cross-sectional study," The Journal of Pain, vol. 20, no. 3, pp. 288-300, 2019.

[11] W. Hiller, M. M. Fichter, and W. Rief, "A controlled treatment study of somatoform disorders including analysis of healthcare utilization and cost-effectiveness," Journal of Psychosomatic Research, vol. 54, no. 4, pp. 369-380, 2003.

[12] D. D. Jeffery, L. Bulathsinhala, M. Kroc, and J. Dorris, "Prevalence, health care utilization, and costs of fibromyalgia, irritable bowel, and chronic fatigue syndromes in the military health system, 2006-2010," Military Medicine, vol. 179, no. 9, pp. 1021-1029, 2014.

[13] C. Hausteiner-Wiehle and P. Henningsen, "Irritable bowel syndrome: relations with functional, mental, and somatoform disorders," World Journal of Gastroenterology, vol. 20, no. 20, pp. 6024-6030, 2014.

[14] I. Ayouni, R. Chebbi, Z. Hela, and M. Dhidah, "Comorbidity between fibromyalgia and temporomandibular disorders: a systematic review," Oral Surgery, Oral Medicine, Oral Pathology, Oral Radiology, vol. 128, no. 1, pp. 33-42, 2019.

[15] M. Zhuo and G. F. Gebhart, "Biphasic modulation of spinal nociceptive transmission from the medullary raphe nuclei in the rat," Journal of Neurophysiology, vol. 78, no. 2, pp. 746-758, 1997.

[16] T. Chen, W. Taniguchi, Q. Y. Chen et al., "Top-down descending facilitation of spinal sensory excitatory transmission from the anterior cingulate cortex," Nature Communications, vol. 9, no. 1, article 1886, 2018.

[17] W. Wang, X. Zhong, Y. Li et al., "Rostral ventromedial medulla-mediated descending facilitation following $\mathrm{p} 2 \mathrm{x} 7$ receptor activation is involved in the development of chronic post-operative pain," Journal of Neurochemistry, vol. 149, no. 6, pp. 760-780, 2019.

[18] A. David-Pereira, B. Sagalajev, H. Wei, A. Almeida, A. Pertovaara, and F. Pinto-Ribeiro, "The medullary dorsal reticular nucleus as a relay for descending pronociception induced by the mglur5 in the rat infralimbic cortex," Neuroscience, vol. 349, pp. 341-354, 2017.

[19] S. F. Li, Y. Y. Zhang, Y. Y. Li, S. Wen, and Z. Xiao, "Antihyperalgesic effect of $5-\mathrm{HT}_{7}$ receptor activation on the midbrain periaqueductal gray in a rat model of neuropathic pain," Pharmacology, Biochemistry, and Behavior, vol. 127, pp. 49-55, 2014.

[20] O. A. Lyubashina and I. B. Sivachenko, "The 5-HT 4 receptormediated inhibition of visceral nociceptive neurons in the rat caudal ventrolateral medulla," Neuroscience, vol. 359, pp. 277-288, 2017.

[21] M. H. Ossipov, K. Morimura, and F. Porreca, "Descending pain modulation and chronification of pain," Current Opinion in Supportive and Palliative Care, vol. 8, no. 2, pp. 143151, 2014.

[22] P. Boadas-Vaello, J. Homs, F. Reina, A. Carrera, and E. Verdu, "Neuroplasticity of supraspinal structures 
associated with pathological pain," The Anatomical Record, vol. 300, no. 8, pp. 1481-1501, 2017.

[23] R. Suzuki, L. J. Rygh, and A. H. Dickenson, "Bad news from the brain: descending 5-HT pathways that control spinal pain processing," Trends in Pharmacological Sciences, vol. 25, no. 12, pp. 613-617, 2004.

[24] J. S. M. Chia, A. A. Omar Farouk, A. S. Mohamad, M. R. Sulaiman, and E. K. Perimal, "Zerumbone alleviates chronic constriction injury-induced allodynia and hyperalgesia through serotonin 5-HT receptors," Biomedicine \& Pharmacotherapy, vol. 83, pp. 1303-1310, 2016.

[25] J. H. Atkinson, M. A. Slater, D. R. Wahlgren et al., "Effects of noradrenergic and serotonergic antidepressants on chronic low back pain intensity," Pain, vol. 83, no. 2, pp. 137-145, 1999.

[26] Z. Q. Zhao, S. Chiechio, Y. G. Sun et al., "Mice lacking central serotonergic neurons show enhanced inflammatory pain and an impaired analgesic response to antidepressant drugs," The Journal of Neuroscience, vol. 27, no. 22, pp. 6045-6053, 2007.

[27] A. P. Brietzke, L. C. Antunes, F. Carvalho et al., "Potency of descending pain modulatory system is linked with peripheral sensory dysfunction in fibromyalgia: an exploratory study," Medicine, vol. 98, no. 3, article e13477, 2019.

[28] R. J. Chakiath, P. J. Siddall, J. E. Kellow et al., "Descending pain modulation in irritable bowel syndrome (IBS): a systematic review and meta-analysis," Systematic Reviews, vol. 4, no. 1, article 175, 2015.

[29] P. Henningsen, S. Zipfel, and W. Herzog, "Management of functional somatic syndromes," The Lancet, vol. 369, no. 9565, pp. 946-955, 2007.

[30] U. Isong, S. A. Gansky, and O. Plesh, “Temporomandibular joint and muscle disorder-type pain in U.S. adults: the National Health Interview Survey," Journal of Orofacial Pain, vol. 22, no. 4, pp. 317-322, 2008.

[31] Y. A. Saito, P. Schoenfeld, and G. R. Locke 3rd, “The epidemiology of irritable bowel syndrome in North America: a systematic review," The American Journal of Gastroenterology, vol. 97, no. 8, pp. 1910-1915, 2002.

[32] L. P. Queiroz, "Worldwide epidemiology of fibromyalgia," Current Pain and Headache Reports, vol. 17, no. 8, p. 356, 2013.

[33] K. Kroenke and R. K. Price, "Symptoms in the Community," Archives of Internal Medicine, vol. 153, no. 21, pp. 2474-2480, 1993.

[34] M. L. Paras, M. H. Murad, L. P. Chen et al., "Sexual abuse and lifetime diagnosis of somatic disorders: a systematic review and meta-analysis," JAMA, vol. 302, no. 5, pp. 550-561, 2009.

[35] H. Haller, H. Cramer, R. Lauche, and G. Dobos, "Somatoform disorders and medically unexplained symptoms in primary care. A systematic review and meta-analysis of prevalence," Deutsches Ärzteblatt International, vol. 112, no. 16, pp. 279-287, 2015.

[36] B. Lowe, R. L. Spitzer, J. B. Williams, M. Mussell, D. Schellberg, and K. Kroenke, "Depression, anxiety and somatization in primary care: syndrome overlap and functional impairment," General Hospital Psychiatry, vol. 30, no. 3, pp. 191-199, 2008.

[37] L. A. Page and S. Wessely, "Medically unexplained symptoms: exacerbating factors in the doctor-patient encounter," Journal of the Royal Society of Medicine, vol. 96, no. 5, pp. 223-227, 2003.
[38] B. Salvioli, G. Pellegatta, M. Malacarne et al., "Autonomic nervous system dysregulation in irritable bowel syndrome," Neurogastroenterology and Motility, vol. 27, no. 3, pp. 423-430, 2015.

[39] L. M. Tak, A. J. Cleare, J. Ormel et al., "Meta-analysis and meta-regression of hypothalamic-pituitary-adrenal axis activity in functional somatic disorders," Biological Psychology, vol. 87, no. 2, pp. 183-194, 2011.

[40] D. A. Williams and D. J. Clauw, "Understanding fibromyalgia: lessons from the broader pain research community," The Journal of Pain, vol. 10, no. 8, pp. 777-791, 2009.

[41] B. Cagnie, I. Coppieters, S. Denecker, J. Six, L. Danneels, and M. Meeus, "Central sensitization in fibromyalgia? A systematic review on structural and functional brain MRI," Seminars in Arthritis and Rheumatism, vol. 44, no. 1, pp. 68-75, 2014.

[42] S. T. Witt, O. Bednarska, A. V. Keita et al., "Interactions between gut permeability and brain structure and function in health and irritable bowel syndrome," NeuroImage: Clinical, vol. 21, article 101602, 2019.

[43] I. Low, S. Y. Wei, P. S. Lee et al., "Neuroimaging studies of primary dysmenorrhea," Advances in Experimental Medicine and Biology, vol. 1099, pp. 179-199, 2018.

[44] P. C. Conti, Y. M. Costa, D. A. Goncalves, and P. Svensson, "Headaches and myofascial temporomandibular disorders: overlapping entities, separate managements?," Journal of Oral Rehabilitation, vol. 43, no. 9, pp. 702-715, 2016.

[45] H. J. You, J. Lei, M. Y. Sui et al., "Endogenous descending modulation: spatiotemporal effect of dynamic imbalance between descending facilitation and inhibition of nociception," The Journal of Physiology, vol. 588, no. 21, pp. 4177-4188, 2010.

[46] M. J. Millan, "Descending control of pain," Progress in Neurobiology, vol. 66, no. 6, pp. 355-474, 2002.

[47] A. Dogrul, M. H. Ossipov, and F. Porreca, "Differential mediation of descending pain facilitation and inhibition by spinal 5HT-3 and 5HT-7 receptors," Brain Research, vol. 1280, pp. 52-59, 2009.

[48] M. Sasaki, H. Obata, K. Kawahara, S. Saito, and F. Goto, "Peripheral 5-HT2A receptor antagonism attenuates primary thermal hyperalgesia and secondary mechanical allodynia after thermal injury in rats," Pain, vol. 122, no. 1, pp. 130136, 2006.

[49] D. Hoyer, D. E. Clarke, J. R. Fozard et al., "International union of pharmacology classification of receptors for 5-hydroxytryptamine (serotonin)," Pharmacological Reviews, vol. 46, no. 2, pp. 157-203, 1994.

[50] V. M. Goettl, Y. Huang, K. V. Hackshaw, and R. L. Stephens Jr., "Reduced basal release of serotonin from the ventrobasal thalamus of the rat in a model of neuropathic pain," Pain, vol. 99, no. 1, pp. 359-366, 2002.

[51] S. Sounvoravong, M. N. Nakashima, M. Wada, and K. Nakashima, "Decrease in serotonin concentration in raphe magnus nucleus and attenuation of morphine analgesia in two mice models of neuropathic pain," European Journal of Pharmacology, vol. 484, no. 2-3, pp. 217-223, 2004.

[52] E. Palazzo, R. Genovese, L. Mariani et al., "Metabotropic glutamate receptor 5 and dorsal raphe serotonin release in inflammatory pain in rat," European Journal of Pharmacology, vol. 492, no. 2-3, pp. 169-176, 2004.

[53] I. J. Russell, J. E. Michalek, G. A. Vipraio, E. M. Fletcher, M. A. Javors, and C. A. Bowden, "Platelet 3h-imipramine 
uptake receptor density and serum serotonin levels in patients with fibromyalgia/fibrositis syndrome," The Journal of Rheumatology, vol. 19, no. 1, pp. 104-109, 1992.

[54] N. M. Barnes and T. Sharp, "A review of central 5-HT receptors and their function," Neuropharmacology, vol. 38, no. 8, pp. 1083-1152, 1999.

[55] W. Rahman, C. S. Bauer, K. Bannister, J. L. Vonsy, A. C. Dolphin, and A. H. Dickenson, "Descending serotonergic facilitation and the antinociceptive effects of pregabalin in a rat model of osteoarthritic pain," Molecular Pain, vol. 5, article 45, 2009.

[56] Y. S. Su, Y. Y. Chiu, S. Y. Lin, C. C. Chen, and W. H. Sun, "Serotonin receptor $2 \mathrm{~b}$ mediates mechanical hyperalgesia by regulating transient receptor potential vanilloid 1," Journal of Molecular Neuroscience, vol. 59, no. 1, pp. 113-125, 2016.

[57] K. Bannister, L. A. Bee, and A. H. Dickenson, "Preclinical and early clinical investigations related to monoaminergic pain modulation," Neurotherapeutics, vol. 6, no. 4, pp. 703-712, 2009.

[58] A. G. Aksu, O. Gunduz, and A. Ulugol, "Contribution of spinal $5-\mathrm{HT}_{5 \mathrm{~A}}$ receptors to the antinociceptive effects of systemically administered cannabinoid agonist win 55,212-2 and morphine," Canadian Journal of Physiology and Pharmacology, vol. 96, no. 6, pp. 618-623, 2018.

[59] J. L. Cortes-Altamirano, A. Olmos-Hernandez, H. B. Jaime et al., "Review: 5-HT1, 5-HT2, 5-HT3 and 5-HT7 receptors and their role in the modulation of pain response in the central nervous system," Current Neuropharmacology, vol. 16, no. 2, pp. 210-221, 2018.

[60] P. P. Humphrey, P. Hartig, and D. Hoyer, "A proposed new nomenclature for 5-HT receptors," Trends in Pharmacological Sciences, vol. 14, no. 6, pp. 233-236, 1993.

[61] O. A. Lyubashina, I. I. Busygina, S. S. Panteleev, and A. D. Nozdrachev, "Antinociceptive effect of the agonist of 5-HT1A receptors buspirone in the model of abdominal pain in dogs," Doklady Biological Sciences, vol. 473, no. 1, pp. 46-49, 2017.

[62] H. Miwa, A. Nagahara, K. Tominaga et al., "Efficacy of the 5-HT1a agonist tandospirone citrate in improving symptoms of patients with functional dyspepsia: a randomized controlled trial," The American Journal of Gastroenterology, vol. 104, no. 11, pp. 2779-2787, 2009.

[63] B. Sagalajev, H. Viisanen, H. Wei, and A. Pertovaara, "Descending antinociception induced by secondary somatosensory cortex stimulation in experimental neuropathy: role of the medullospinal serotonergic pathway," Journal of Neurophysiology, vol. 117, no. 3, pp. 1200-1214, 2017.

[64] P. S. Rojas and J. L. Fiedler, "What do we really know about $5-\mathrm{HT}_{1 \mathrm{~A}}$ receptor signaling in neuronal cells?," Frontiers in Cellular Neuroscience, vol. 10, p. 272, 2016.

[65] V. Kayser, I. E. Elfassi, B. Aubel et al., "Mechanical, thermal and formalin-induced nociception is differentially altered in 5-HT1A-/-, 5-HT1B-/-, 5-HT2A-/-, 5-HT3A-/- and 5-HTT-/- knock-out male mice," Pain, vol. 130, no. 3, pp. 235-248, 2007.

[66] Y. Zhang, A. Li, J. Xin et al., "Electroacupuncture alleviates chemotherapy-induced pain through inhibiting phosphorylation of spinal CaMKII in rats," European Journal of Pain, vol. 22, no. 4, pp. 679-690, 2018.

[67] Y. J. Huang and J. W. Grau, "Ionic plasticity and pain: the loss of descending serotonergic fibers after spinal cord injury transforms how GABA affects pain," Experimental Neurology, vol. 306, pp. 105-116, 2018.

[68] I. S. Choi, J. H. Cho, and I. S. Jang, "5-Hydroxytryptamine 1a receptors inhibit glutamate release in rat medullary dorsal horn neurons," Neuroreport, vol. 24, no. 8, pp. 399-403, 2013.

[69] Z. Tian, M. Yamanaka, M. Bernabucci, M. G. Zhao, and M. Zhuo, "Characterization of serotonin-induced inhibition of excitatory synaptic transmission in the anterior cingulate cortex," Molecular Brain, vol. 10, no. 1, p. 21, 2017.

[70] F. Q. Huo, C. L. Qu, Y. Q. Li, J. S. Tang, and H. Jia, “Gabaergic modulation is involved in the ventrolateral orbital cortex 5-HT1A receptor activation-induced antinociception in the rat," Pain, vol. 139, no. 2, pp. 398-405, 2008.

[71] B. Sagalajev, N. Bourbia, E. Beloushko, H. Wei, and A. Pertovaara, "Bidirectional amygdaloid control of neuropathic hypersensitivity mediated by descending serotonergic pathways acting on spinal 5- $\mathrm{HT}_{3}$ and $5-\mathrm{HT}_{1 \mathrm{a}}$ receptors," Behavioural Brain Research, vol. 282, pp. 14-24, 2015.

[72] K. Deseure, W. Koek, H. Adriaensen, and F. C. Colpaert, "Continuous administration of the 5-hydroxytryptamine ${ }_{1 \mathrm{~A}}$ agonist (3-Chloro-4-fluoro-phenyl)-[4-fluoro-4-\{[(5-methyl -pyridin-2-ylmethyl) -amino]-methyl\}piperidin-1-yl]-methadone (F 13640) attenuates allodynia-like behavior in a rat model of trigeminal neuropathic pain," Journal of Pharmacology and Experimental Therapeutics, vol. 306, no. 2, pp. 505-514, 2003.

[73] L. A. Bruins Slot, W. Koek, J. P. Tarayre, and F. C. Colpaert, "Tolerance and inverse tolerance to the hyperalgesic and analgesic actions, respectively, of the novel analgesic, f 13640," European Journal of Pharmacology, vol. 466, no. 3, pp. 271-279, 2003.

[74] A. Negro, A. Koverech, and P. Martelletti, "Serotonin receptor agonists in the acute treatment of migraine: a review on their therapeutic potential," Journal of Pain Research, vol. 11, pp. 515-526, 2018.

[75] M. Farkkila, H. C. Diener, G. Geraud et al., "Efficacy and tolerability of lasmiditan, an oral $5-\mathrm{HT}_{1 \mathrm{~F}}$ receptor agonist, for the acute treatment of migraine: a phase 2 randomised, placebo-controlled, parallel-group, dose-ranging study," The Lancet Neurology, vol. 11, no. 5, pp. 405-413, 2012.

[76] H. J. Jeong, D. Chenu, E. E. Johnson, M. Connor, and C. W. Vaughan, "Sumatriptan inhibits synaptic transmission in the rat midbrain periaqueductal grey," Molecular Pain, vol. 4, article 54, 2008.

[77] L. P. Vera-Portocarrero, M. H. Ossipov, T. King, and F. Porreca, "Reversal of inflammatory and noninflammatory visceral pain by central or peripheral actions of sumatriptan," Gastroenterology, vol. 135, no. 4, pp. 1369-1378, 2008.

[78] E. A. Jennings, R. M. Ryan, and M. J. Christie, "Effects of sumatriptan on rat medullary dorsal horn neurons," Pain, vol. 111, no. 1, pp. 30-37, 2004.

[79] S. H. Avila-Rojas, I. Velazquez-Lagunas, A. B. SalinasAbarca, P. Barragan-Iglesias, J. B. Pineda-Farias, and

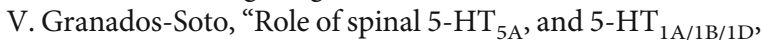
receptors in neuropathic pain induced by spinal nerve ligation in rats," Brain Research, vol. 1622, pp. 377-385, 2015.

[80] Z. Aira, I. Buesa, M. Salgueiro et al., "Subtype-specific changes in 5-HT receptor-mediated modulation of C fibreevoked spinal field potentials are triggered by peripheral nerve injury," Neuroscience, vol. 168, no. 3, pp. 831-841, 2010 . 
[81] I. Vinuela-Fernandez, L. Sun, H. Jerina et al., "The TRPM8 channel forms a complex with the $5-\mathrm{HT}_{1 \mathrm{~B}}$ receptor and phospholipase $\mathrm{D}$ that amplifies its reversal of pain hypersensitivity," Neuropharmacology, vol. 79, pp. 136-151, 2014.

[82] J. Van Steenwinckel, A. Noghero, K. Thibault, M. J. Brisorgueil, J. Fischer, and M. Conrath, "The 5-HT2A receptor is mainly expressed in nociceptive sensory neurons in rat lumbar dorsal root ganglia," Neuroscience, vol. 161, no. 3, pp. 838-846, 2009.

[83] H. Xie, Z. Q. Dong, F. Ma, W. R. Bauer, X. Wang, and G. C. $\mathrm{Wu}$, "Involvement of serotonin $2 \mathrm{~A}$ receptors in the analgesic effect of tramadol in mono-arthritic rats," Brain Research, vol. 1210, pp. 76-83, 2008.

[84] R. de Oliveira, R. C. de Oliveira, L. L. Falconi-Sobrinho, R. da Silva Soares Jr., and N. C. Coimbra, "5-Hydroxytryptamine $_{2 \mathrm{~A} / 2 \mathrm{C}}$ receptors of nucleus raphe magnus and gigantocellularis/paragigantocellularis pars alpha reticular nuclei modulate the unconditioned fear-induced antinociception evoked by electrical stimulation of deep layers of the superior colliculus and dorsal periaqueductal grey matter," Behavioural Brain Research, vol. 316, pp. 294-304, 2017.

[85] R. L. de Freitas, P. Medeiros, J. A. da Silva et al., "The $\mu_{1}$-opioid receptor and $5-\mathrm{HT}_{2 \mathrm{~A}^{-}}$and $5 \mathrm{HT}_{2 \mathrm{C}}$-serotonergic receptors of the locus coeruleus are critical in elaborating hypoalgesia induced by tonic and tonic-clonic seizures," Neuroscience, vol. 336, pp. 133-145, 2016.

[86] R. L. Freitas, G. S. Bassi, A. M. de Oliveira, and N. C. Coimbra, "Serotonergic neurotransmission in the dorsal raphe nucleus recruits in situ $5-\mathrm{HT}_{2 \mathrm{~A} / 2 \mathrm{C}}$ receptors to modulate the post-ictal antinociception," Experimental Neurology, vol. 213, no. 2, pp. 410-418, 2008.

[87] R. L. de Freitas, R. C. de Oliveira, R. de Oliveira, T. Paschoalin-Maurin, F. M. de Aguiar Correa, and N. C. Coimbra, "The role of dorsomedial and ventrolateral columns of the periaqueductal gray matter and in situ $5-\mathrm{HT}_{2 \mathrm{~A}}$ and $5-\mathrm{HT}_{2 \mathrm{C}}$ serotonergic receptors in post-ictal antinociception," Synapse, vol. 68, no. 1, pp. 16-30, 2014.

[88] G. Ji, W. Zhang, L. Mahimainathan et al., "5-HT 2 Ceceptor knockdown in the amygdala inhibits neuropathic-painrelated plasticity and behaviors," The Journal of Neuroscience, vol. 37, no. 6, pp. 1378-1393, 2017.

[89] S. Gregoire and V. Neugebauer, " $5-\mathrm{HT}_{2 \mathrm{C}} \mathrm{R}$ blockade in the amygdala conveys analgesic efficacy to ssris in a rat model of arthritis pain," Molecular Pain, vol. 9, article 41, 2013.

[90] C. Cervantes-Durán, G. C. Vidal-Cantú, B. GodinezChaparro, and V. Granados-Soto, "Role of spinal 5- $\mathrm{HT}_{2}$ receptors subtypes in formalin- induced long-lasting hypersensitivity," Pharmacological Reports, vol. 68, no. 2, pp. 434-442, 2016.

[91] A. Kjorsvik, A. Tjolsen, and K. Hole, “Activation of spinal serotonin $_{2 \mathrm{~A} / 2 \mathrm{C}}$ receptors augments nociceptive responses in the rat," Brain Research, vol. 910, no. 1-2, pp. 179-181, 2001.

[92] H. Obata, N. Ito, M. Sasaki, S. Saito, and F. Goto, "Possible involvement of spinal noradrenergic mechanisms in the antiallodynic effect of intrathecally administered $5-\mathrm{HT}_{2 \mathrm{c}}$ receptor agonists in the rats with peripheral nerve injury," European Journal of Pharmacology, vol. 567, no. 1-2, pp. 89-94, 2007.

[93] M. Honda, K. Uchida, M. Tanabe, and H. Ono, "Fluvoxamine, a selective serotonin reuptake inhibitor, exerts its antiallodynic effects on neuropathic pain in mice via $5-\mathrm{HT}_{2 \mathrm{a} / 2 \mathrm{c}}$ receptors," Neuropharmacology, vol. 51, no. 4, pp. 866-872, 2006.

[94] C. Alba-Delgado, S. Mountadem, N. Mermet-Joret et al., "5- $\mathrm{HT}_{2 \mathrm{~A}}$ Receptor-Induced morphological reorganization of PKC $\gamma$-Expressing interneurons gates inflammatory mechanical allodynia in rat," The Journal of Neuroscience, vol. 38, no. 49, pp. 10489-10504, 2018.

[95] Z. Aira, I. Buesa, M. Gallego et al., "Time-dependent cross talk between spinal serotonin $5-\mathrm{ht}_{2 \mathrm{~A}}$ receptor and mglur1 subserves spinal hyperexcitability and neuropathic pain after nerve injury," The Journal of Neuroscience, vol. 32, no. 39, pp. 13568-13581, 2012.

[96] R. Bos, K. Sadlaoud, P. Boulenguez et al., "Activation of 5 -ht 2 a receptors upregulates the function of the neuronal $\mathrm{k}-\mathrm{cl}$ cotransporter kcc2," Proceedings of the National Academy of Sciences of the United States of America, vol. 110, no. 1, pp. 348-353, 2013.

[97] R. Dong, B. Yu, L. Chen, and W. Yu, "The 5-HT2A receptor potassium-chloride cotransporter 2 signaling pathway in a rat incision pain model," Experimental and Therapeutic Medicine, vol. 12, no. 6, pp. 3583-3588, 2016.

[98] I. Sanchez-Brualla, P. Boulenguez, C. Brocard et al., "Activation of $5-\mathrm{ht}_{2 \mathrm{~A}}$ receptors restores kcc2 function and reduces neuropathic pain after spinal cord injury," Neuroscience, vol. 387, pp. 48-57, 2018.

[99] X. Pichon, A. S. Wattiez, C. Becamel et al., "Disrupting $5-\mathrm{HT}_{2 \mathrm{~A}}$ Receptor/PDZ protein interactions reduces hyperalgesia and enhances ssri efficacy in neuropathic pain," Molecular Therapy, vol. 18, no. 8, pp. 1462-1470, 2010.

[100] A. S. Wattiez, X. Pichon, A. Dupuis et al., "Disruption of $5-\mathrm{HT}_{2 \mathrm{~A}}$ receptor-PDZ protein interactions alleviates mechanical hypersensitivity in carrageenan-induced inflammation in rats," PLoS One, vol. 8, no. 9, article e74661, 2013.

[101] A. S. Wattiez, A. Dupuis, A. M. Privat et al., "Disruption of $5-\mathrm{HT}_{2 \mathrm{~A}}-\mathrm{pdz}$ protein interaction differently affects the analgesic efficacy of SSRI, SNRI and TCA in the treatment of traumatic neuropathic pain in rats," Neuropharmacology, vol. 125, pp. 308-318, 2017.

[102] A. Dupuis, A. S. Wattiez, J. Pinguet et al., "Increasing spinal $5-\mathrm{HT}_{2 \mathrm{~A}}$ receptor responsiveness mediates anti-allodynic effect and potentiates fluoxetine efficacy in neuropathic rats. Evidence for GABA release," Pharmacological Research, vol. 118, pp. 93-103, 2017.

[103] T. Ochi, M. Sakamoto, A. Minamida et al., "Syntheses and properties of the major hydroxy metabolites in humans of blonanserin AD-5423, a novel antipsychotic agent," Bioorganic \& Medicinal Chemistry Letters, vol. 15, no. 4, pp. 1055-1059, 2005.

[104] L. K. Burke, E. Ogunnowo-Bada, T. Georgescu et al., "Lorcaserin improves glycemic control via a melanocortin neurocircuit," Molecular Metabolism, vol. 6, no. 10, pp. 1092-1102, 2017.

[105] J. B. Pineda-Farias, I. Velazquez-Lagunas, P. BarraganIglesias, C. Cervantes-Duran, and V. Granados-Soto, "5- $\mathrm{HT}_{2 \mathrm{~B}}$ Receptor antagonists reduce nerve injury-induced tactile allodynia and expression of 5- $\mathrm{HT}_{2 \mathrm{~B}}$ Receptors," Drug Development Research, vol. 76, no. 1, pp. 31-39, 2015.

[106] Z. Aira, I. Buesa, G. Garcia del Cano et al., "Transient, 5-HT2B receptor-mediated facilitation in neuropathic pain: up-regulation of PKC $\gamma$ and engagement of the NMDA receptor in dorsal horn neurons," Pain, vol. 154, no. 9, pp. 1865-1877, 2013. 
[107] S. M. O'Mahony, D. C. Bulmer, A. M. Coelho et al., "5- $\mathrm{HT}_{2 \mathrm{~B}}$ receptors modulate visceral hypersensitivity in a stresssensitive animal model of brain-gut axis dysfunction," Neurogastroenterology and Motility, vol. 22, no. 5, article 573-e124, 2010.

[108] P. A. Davies, M. Pistis, M. C. Hanna et al., "The 5-HT ${ }_{3 B}$ subunit is a major determinant of serotonin-receptor function," Nature, vol. 397, no. 6717, pp. 359-363, 1999.

[109] B. Niesler, J. Walstab, S. Combrink et al., "Characterization of the novel human serotonin receptor subunits 5- $\mathrm{HT}_{3 \mathrm{C}}, 5-\mathrm{HT}_{3 \mathrm{D}}$, and 5- $\mathrm{HT}_{3 \mathrm{E}}$," Molecular Pharmacology, vol. 72, no. 1, pp. 8-17, 2007.

[110] T. J. Gan, "Selective serotonin 5-HT3 receptor antagonists for postoperative nausea and vomiting: are they all the same?," CNS Drugs, vol. 19, no. 3, pp. 225-238, 2005.

[111] W. Rahman, R. Suzuki, L. J. Rygh, and A. H. Dickenson, "Descending serotonergic facilitation mediated through rat spinal 5HT3 receptors is unaltered following carrageenan inflammation," Neuroscience Letters, vol. 361, no. 1-3, pp. 229-231, 2004.

[112] R. Okazaki, H. Namba, H. Yoshida, H. Okai, T. Miura, and M. Kawamura, "The antiallodynic effect of neurotropin is mediated via activation of descending pain inhibitory systems in rats with spinal nerve ligation," Anesthesia and Analgesia, vol. 107, no. 3, pp. 1064-1069, 2008.

[113] K. P. Zeitz, N. Guy, A. B. Malmberg et al., "The 5-HT3 subtype of serotonin receptor contributes to nociceptive processing via a novel subset of myelinated and unmyelinated nociceptors," The Journal of Neuroscience, vol. 22, no. 3, pp. 1010-1019, 2002.

[114] B. Greenwood-Van Meerveld, E. Mohammadi, K. Tyler, C. Pietra, L. A. Bee, and A. Dickenson, "Synergistic effect of 5-hydroxytryptamine 3 and neurokinin 1 receptor antagonism in rodent models of somatic and visceral pain," The Journal of Pharmacology and Experimental Therapeutics, vol. 351, no. 1, pp. 146-152, 2014.

[115] Y. Chen, M. A. Oatway, and L. C. Weaver, "Blockade of the 5-HT3 receptor for days causes sustained relief from mechanical allodynia following spinal cord injury," Journal of Neuroscience Research, vol. 87, no. 2, pp. 418-424, 2009.

[116] T. Donovan-Rodriguez, C. E. Urch, and A. H. Dickenson, "Evidence of a role for descending serotonergic facilitation in a rat model of cancer-induced bone pain," Neuroscience Letters, vol. 393, no. 2-3, pp. 237-242, 2006.

[117] D. Y. Liang, X. Li, and J. D. Clark, "5-Hydroxytryptamine type 3 receptor modulates opioid-induced hyperalgesia and tolerance in mice," Anesthesiology, vol. 114, no. 5, pp. 11801189, 2011.

[118] J. D. Hall, C. DeWitte, T. J. Ness, and M. T. Robbins, "Serotonin enhances urinary bladder nociceptive processing via a $5-\mathrm{HT}_{3}$ receptor mechanism," Neuroscience Letters, vol. 604, pp. 97-102, 2015.

[119] W. Guo, K. Miyoshi, R. Dubner et al., "Spinal 5-HT 3 receptors mediate descending facilitation and contribute to behavioral hypersensitivity via a reciprocal neuron-glial signaling cascade," Molecular Pain, vol. 10, no. 35, pp. 1744-8069, 2014.

[120] Y. W. Min and P. L. Rhee, "The clinical potential of ramosetron in the treatment of irritable bowel syndrome with diarrhea (IBS-D)," Therapeutic Advances in Gastroenterology, vol. 8, no. 3, pp. 136-142, 2015.
[121] S. Fukudo, M. Ida, H. Akiho, Y. Nakashima, and K. Matsueda, "Effect of ramosetron on stool consistency in male patients with irritable bowel syndrome with diarrhea," Clinical Gastroenterology and Hepatology, vol. 12, no. 6, pp. 953-959.e4, 2014.

[122] K. J. Lee, N. Y. Kim, J. K. Kwon et al., "Efficacy of ramosetron in the treatment of male patients with irritable bowel syndrome with diarrhea: a multicenter, randomized clinical trial, compared with mebeverine," Neurogastroenterology and Motility, vol. 23, no. 12, pp. 1098-1104, 2011.

[123] T. Funatsu, A. Takeuchi, T. Hirata, Y. Keto, S. Akuzawa, and M. Sasamata, "Effect of ramosetron on conditioned emotional stress-induced colonic dysfunction as a model of irritable bowel syndrome in rats," European Journal of Pharmacology, vol. 573, no. 1-3, pp. 190-195, 2007.

[124] N. Christidis, S. Omrani, L. Fredriksson et al., "Repeated tender point injections of granisetron alleviate chronic myofascial pain - a randomized, controlled, double-blinded trial," The Journal of Headache and Pain, vol. 16, no. 1, p. 104, 2015.

[125] M. F. Seidel, G. F. Weinreich, T. Stratz, and W. Muller, "5-HT3 receptor antagonists regulate autonomic cardiac dysfunction in primary fibromyalgia syndrome," Rheumatology International, vol. 27, no. 11, pp. 1025-1030, 2007.

[126] P. Vergne-Salle, C. Dufauret-Lombard, C. Bonnet et al., "A randomised, double-blind, placebo-controlled trial of dolasetron, a 5-hydroxytryptamine 3 receptor antagonist, in patients with fibromyalgia," European Journal of Pain, vol. 15, no. 5, pp. 509-514, 2011.

[127] Z. L. Li, Y. Xue, Z. Y. Tao, W. Z. Du, Y. G. Jiang, and D. Y. Cao, "Spinal 5-HT3 receptor contributes to somatic hyperalgesia induced by sub-chronic stress," Molecular Pain, vol. 15, 2019.

[128] H. Wolf, "Preclinical and clinical pharmacology of the 5-HT3 receptor antagonists," Scandinavian Journal of Rheumatology Supplement, vol. 113, pp. 37-45, 2000.

[129] J. M. Hoffman, K. Tyler, S. J. Mac Eachern et al., “Activation of colonic mucosal $5-\mathrm{HT}_{4}$ receptors accelerates propulsive motility and inhibits visceral hypersensitivity," Gastroenterology, vol. 142, no. 4, pp. 844-854.e4, 2012.

[130] T. Manzke, U. Guenther, E. G. Ponimaskin et al., "5-HT 4 (a) receptors avert opioid-induced breathing depression without loss of analgesia," Science, vol. 301, no. 5630, pp. 226-229, 2003.

[131] H. J. Kim, S. H. Lee, E. A. Lim, and J. S. Kim, "Formulation optimization of solid dispersion of mosapride hydrochloride," Archives of Pharmacal Research, vol. 34, no. 9, pp. 1467-1475, 2011.

[132] J. M. Sabate, D. Bouhassira, C. Poupardin, A. Wagner, Y. Loria, and B. Coffin, "Sensory signalling effects of tegaserod in patients with irritable bowel syndrome with constipation," Neurogastroenterology and Motility, vol. 20, no. 2, pp. 134-141, 2008.

[133] J. N. Sengupta, A. Mickle, P. Kannampalli et al., "Visceral analgesic effect of $5-\mathrm{HT}_{4}$ receptor agonist in rats involves the rostroventral medulla (RVM)," Neuropharmacology, vol. 79, pp. 345-358, 2014.

[134] F. Y. Liu, G. G. Xing, X. X. Qu, I. S. Xu, J. S. Han, and Y. Wan, "Roles of 5-hydroxytryptamine (5-HT) receptor subtypes in the inhibitory effects of 5-ht on c-fiber responses of spinal wide dynamic range neurons in rats," The Journal of Pharmacology and Experimental Therapeutics, vol. 321, no. 3, pp. 1046-1053, 2007. 
[135] B. Godinez-Chaparro, F. J. Lopez-Santillan, P. Orduna, and V. Granados-Soto, "Secondary mechanical allodynia and hyperalgesia depend on descending facilitation mediated by spinal 5- $\mathrm{HT}_{4}, 5-\mathrm{HT}_{6}$ and 5- $\mathrm{HT}_{7}$ receptors," Neuroscience, vol. 222, pp. 379-391, 2012.

[136] M. G. Erlander, T. W. Lovenberg, B. M. Baron et al., "Two members of a distinct subfamily of 5-hydroxytryptamine receptors differentially expressed in rat brain," Proceedings of the National Academy of Sciences of the United States of America, vol. 90, no. 8, pp. 3452-3456, 1993.

[137] H. Matthes, U. Boschert, N. Amlaiky et al., "Mouse 5-hydroxytryptamine 5a and 5-hydroxytryptamine5b receptors define a new family of serotonin receptors: cloning, functional expression, and chromosomal localization," Molecular Pharmacology, vol. 43, no. 3, pp. 313-319, 1993.

[138] R. Grailhe, G. W. Grabtree, and R. Hen, "Human 5- $\mathrm{HT}_{5}$ receptors: the $5-\mathrm{HT}_{5 \mathrm{~A}}$ receptor is functional but the $5-\mathrm{HT}_{5 \mathrm{~B}}$ receptor was lost during mammalian evolution," European Journal of Pharmacology, vol. 418, no. 3, pp. 157-167, 2001.

[139] S. Doly, J. Fischer, M. J. Brisorgueil, D. Verge, and M. Conrath, "5-HT5A receptor localization in the rat spinal cord suggests a role in nociception and control of pelvic floor musculature," The Journal of Comparative Neurology, vol. 476, no. 4, pp. 316-329, 2004.

[140] F. Kassai, C. Schlumberger, R. Kedves et al., "Effect of 5-HT5A antagonists in animal models of schizophrenia, anxiety and depression," Behavioural Pharmacology, vol. 23, no. 4, pp. 397-406, 2012.

[141] R. Gonzalez, K. Chavez-Pascacio, and A. Meneses, "Role of $5-\mathrm{HT}_{5 \mathrm{~A}}$ receptors in the consolidation of memory," Behavioural Brain Research, vol. 252, pp. 246-251, 2013.

[142] S. Lopez-Esparza, L. C. Berumen, K. Padilla, R. Miledi, and G. Garcia-Alcocer, "Expression of hippocampal serotonin receptors $5-\mathrm{HT}_{2 \mathrm{C}}$ and $5-\mathrm{HT}_{5 \mathrm{~A}}$ in a rat model of dietinduced obesity supplemented with tryptophan," International Journal of Developmental Neuroscience, vol. 42, pp. 80-85, 2015.

[143] E. Munoz-Islas, G. C. Vidal-Cantu, M. Bravo-Hernandez et al., "Spinal 5- $\mathrm{HT}_{5 \mathrm{~A}}$ receptors mediate 5-HT-induced antinociception in several pain models in rats," Pharmacology, Biochemistry, and Behavior, vol. 120, pp. 25-32, 2014.

[144] G. C. Vidal-Cantu, M. Jimenez-Hernandez, H. I. RochaGonzalez, C. M. Villalon, V. Granados-Soto, and E. Munoz-Islas, "Role of $5-\mathrm{ht}_{5 \mathrm{~A}}$ and $5-\mathrm{ht}_{1 \mathrm{~B} / 1 \mathrm{D}}$ receptors in the antinociception produced by ergotamine and valerenic acid in the rat formalin test," European Journal of Pharmacology, vol. 781, pp. 109-116, 2016.

[145] M. Ruat, E. Traiffort, J. M. Arrang et al., "A novel rat serotonin $\left(5-\mathrm{HT}_{6}\right)$ receptor: molecular cloning, localization and stimulation of camp accumulation," Biochemical and Biophysical Research Communications, vol. 193, no. 1, pp. 268-276, 1993.

[146] J. B. Pineda-Farias, P. Barragan-Iglesias, A. ValdiviesoSanchez et al., "Spinal $5-\mathrm{HT}_{4}$ and $5-\mathrm{HT}_{6}$ receptors contribute to the maintenance of neuropathic pain in rats," Pharmacological Reports, vol. 69, no. 5, pp. 916-923, 2017.

[147] R. Khoury, N. Grysman, J. Gold, K. Patel, and G. T. Grossberg, "The role of 5 HT6-receptor antagonists in Alzheimer's disease: an update," Expert Opinion on Investigational Drugs, vol. 27, no. 6, pp. 523-533, 2018.

[148] P. Jayarajan, R. Nirogi, A. Shinde et al., "5-HT 6 receptor antagonist attenuates the memory deficits associated with neuropathic pain and improves the efficacy of gabapentinoids," Pharmacological Reports, vol. 67, no. 5, pp. 934-942, 2015.

[149] J. R. Hong, H. Choo, and G. Nam, "Neuropathic painalleviating effects of pyrazole-conjugated arylsulfonamides as $5-\mathrm{HT}_{6}$ receptor antagonists," Bioorganic \& Medicinal Chemistry Letters, vol. 27, no. 17, pp. 4146-4149, 2017.

[150] G. Castaneda-Corral, H. I. Rocha-Gonzalez, C. I. AraizaSaldana, M. Ambriz-Tututi, G. C. Vidal-Cantu, and V. Granados-Soto, "Role of peripheral and spinal $5-\mathrm{HT}_{6}$ receptors according to the rat formalin test," Neuroscience, vol. 162, no. 2, pp. 444-452, 2009.

[151] R. L. Freitas, C. M. Ferreira, M. A. Urbina et al., "5-HT1A/1B, 5-HT6, and 5-HT7 serotonergic receptors recruitment in tonic-clonic seizure-induced antinociception: role of dorsal raphe nucleus," Experimental Neurology, vol. 217, no. 1, pp. 16-24, 2009.

[152] O. Manfra, K. Van Craenenbroeck, K. Skieterska et al., "Downregulation of 5-HT7 serotonin receptors by the atypical antipsychotics clozapine and olanzapine. Role of motifs in the c-terminal domain and interaction with gasp-1," ACS Chemical Neuroscience, vol. 6, no. 7, pp. 1206-1218, 2015.

[153] D. E. Heidmann, P. Szot, R. Kohen, and M. W. Hamblin, "Function and distribution of three rat 5-hydroxytryptamine $_{7}\left(5-\mathrm{HT}_{7}\right)$ receptor isoforms produced by alternative splicing," Neuropharmacology, vol. 37, no. 12, pp. 16211632, 1998.

[154] A. Matthys, G. Haegeman, K. Van Craenenbroeck, and P. Vanhoenacker, "Role of the 5-HT7 receptor in the central nervous system: from current status to future perspectives," Molecular Neurobiology, vol. 43, no. 3, pp. 228-253, 2011.

[155] M. Leopoldo, E. Lacivita, F. Berardi, R. Perrone, and P. B. Hedlund, "Serotonin 5-HT7 receptor agents: structureactivity relationships and potential therapeutic applications in central nervous system disorders," Pharmacology \& Therapeutics, vol. 129, no. 2, pp. 120-148, 2011.

[156] A. Dogrul and M. Seyrek, "Systemic morphine produce antinociception mediated by spinal 5-HT7, but not 5-HT1A and 5-HT2 receptors in the spinal cord," British Journal of Pharmacology, vol. 149, no. 5, pp. 498-505, 2006.

[157] S. Doly, J. Fischer, M. J. Brisorgueil, D. Verge, and M. Conrath, "Pre- and postsynaptic localization of the 5-HT7 receptor in rat dorsal spinal cord: immunocytochemical evidence," The Journal of Comparative Neurology, vol. 490, no. 3, pp. 256-269, 2005.

[158] F. Viguier, B. Michot, V. Kayser et al., "GABA, but not opioids, mediates the anti-hyperalgesic effects of $5-\mathrm{HT}_{7}$ receptor activation in rats suffering from neuropathic pain," Neuropharmacology, vol. 63, no. 6, pp. 1093-1106, 2012.

[159] A. Brenchat, X. Nadal, L. Romero et al., "Pharmacological activation of 5-HT7 receptors reduces nerve injury-induced mechanical and thermal hypersensitivity," Pain, vol. 149, no. 3, pp. 483-494, 2010.

[160] L. J. Dam, L. Hai, and Y. M. Ha, "Role of the 5- $\mathrm{HT}_{7}$ receptor in the effects of intrathecal nefopam in neuropathic pain in rats," Neuroscience Letters, vol. 566, pp. 50-54, 2014.

[161] K. Bannister, S. Lockwood, L. Goncalves, R. Patel, and A. H. Dickenson, "An investigation into the inhibitory function of serotonin in diffuse noxious inhibitory controls in the neuropathic rat," European Journal of Pain, vol. 21, no. 4, pp. 750760, 2017. 
[162] E. Amaya-Castellanos, J. B. Pineda-Farias, G. CastanedaCorral et al., "Blockade of $5-\mathrm{HT}_{7}$ receptors reduces tactile allodynia in the rat," Pharmacology, Biochemistry, and Behavior, vol. 99, no. 4, pp. 591-597, 2011.

[163] J. Yang, H. B. Bae, H. G. Ki et al., "Different role of spinal 5-HT(hydroxytryptamine)7 receptors and descending serotonergic modulation in inflammatory pain induced in formalin and carrageenan rat models," British Journal of Anaesthesia, vol. 113, no. 1, pp. 138-147, 2014.

[164] M. Santello, A. Bisco, N. E. Nevian, E. Lacivita, M. Leopoldo, and T. Nevian, "The brain-penetrant $5-\mathrm{HT}_{7}$ receptor agonist LP-211 reduces the sensory and affective components of neuropathic pain," Neurobiology of Disease, vol. 106, pp. 214-221, 2017.

[165] B. C. Zou, L. Dong, Y. Wang, S. H. Wang, and M. B. Cao, "Expression and role of 5-HT7 receptor in brain and intestine in rats with irritable bowel syndrome," Chinese Medical Journal, vol. 120, no. 23, pp. 2069-2074, 2007.

[166] H. Zhu, X. Xiao, Y. Chai, D. Li, X. Yan, and H. Tang, "MiRNA-29a modulates visceral hyperalgesia in irritable bowel syndrome by targeting HTR7," Biochemical and Biophysical Research Communications, vol. 511, no. 3, pp. 671678, 2019.

[167] P. Dharmshaktu, V. Tayal, and B. S. Kalra, "Efficacy of antidepressants as analgesics: a review," Journal of Clinical Pharmacology, vol. 52, no. 1, pp. 6-17, 2012.

[168] K. Lawson, "Tricyclic antidepressants and fibromyalgia: what is the mechanism of action?," Expert Opinion on Investigational Drugs, vol. 11, no. 10, pp. 1437-1445, 2002.

[169] H. Obata, "Analgesic mechanisms of antidepressants for neuropathic pain," International Journal of Molecular Sciences, vol. 18, no. 11, p. 2483, 2017.

[170] C. Cervantes-Duran, H. I. Rocha-Gonzalez, and V. Granados-Soto, "Peripheral and spinal 5-HT receptors participate in the pronociceptive and antinociceptive effects of fluoxetine in rats," Neuroscience, vol. 252, pp. 396-409, 2013.

[171] S. H. Sindrup, M. Otto, N. B. Finnerup, and T. S. Jensen, "Antidepressants in the treatment of neuropathic pain," Basic \& Clinical Pharmacology \& Toxicology, vol. 96, no. 6, pp. 399-409, 2005.

[172] W. Hauser, K. Bernardy, N. Uceyler, and C. Sommer, "Treatment of fibromyalgia syndrome with antidepressants: a meta-analysis," JAMA, vol. 301, no. 2, pp. 198-209, 2009.

[173] W. Hauser, F. Wolfe, T. Tolle, N. Uceyler, and C. Sommer, "The role of antidepressants in the management of fibromyalgia Syndrome," CNS Drugs, vol. 26, no. 4, pp. 297-307, 2012.

[174] F. Rico-Villademoros, M. Slim, and E. P. Calandre, "Amitriptyline for the treatment of fibromyalgia: a comprehensive review," Expert Review of Neurotherapeutics, vol. 15, no. 10, pp. 1123-1150, 2015.

[175] M. P. Lunn, R. A. Hughes, and P. J. Wiffen, "Duloxetine for treating painful neuropathy, chronic pain or fibromyalgia," Cochrane Database of Systematic Reviews, vol. 2014, no. 1, article CD007115, 2014.

[176] L. M. Arnold, E. V. Hess, J. I. Hudson, J. A. Welge, S. E. Berno, and P. E. Keck Jr., "A randomized, placebo-controlled, double-blind, flexible-dose study of fluoxetine in the treatment of women with fibromyalgia," The American Journal of Medicine, vol. 112, no. 3, pp. 191-197, 2002.
[177] D. Goldenberg, M. Mayskiy, C. Mossey, R. Ruthazer, and C. Schmid, "A randomized, double-blind crossover trial of fluoxetine and amitriptyline in the treatment of fibromyalgia," Arthritis and Rheumatism, vol. 39, no. 11, pp. 18521859, 1996.

[178] P. Welsch, N. Uceyler, P. Klose, B. Walitt, and W. Häuser, "Serotonin and noradrenaline reuptake inhibitors (snris) for fibromyalgia," Cochrane Database of Systematic Reviews, no. 2, article CD010292, 2018.

[179] B. Walitt, G. Urrutia, M. B. Nishishinya, S. E. Cantrell, and W. Hauser, "Selective serotonin reuptake inhibitors for fibromyalgia syndrome," Cochrane Database of Systematic Reviews, vol. 2015, no. 6, article CD011735, 2015.

[180] C. Xie, Y. Tang, Y. Wang et al., "Efficacy and safety of antidepressants for the treatment of irritable bowel syndrome: a meta-analysis," PLoS One, vol. 10, no. 8, article e0127815, 2015.

[181] A. Kulak-Bejda, G. Bejda, and N. Waszkiewicz, "Antidepressants for irritable bowel syndrome-A systematic review," Pharmacological Reports, vol. 69, no. 6, pp. 1366-1379, 2017.

[182] R. Rahimi, S. Nikfar, A. Rezaie, and M. Abdollahi, "Efficacy of tricyclic antidepressants in irritable bowel syndrome: a metaanalysis," World Journal of Gastroenterology, vol. 15, no. 13, pp. 1548-1553, 2009.

[183] A. W. Bundeff and C. B. Woodis, "Selective serotonin reuptake inhibitors for the treatment of irritable bowel syndrome," The Annals of Pharmacotherapy, vol. 48, no. 6, pp. 777-784, 2014.

[184] J. Tack, D. Broekaert, B. Fischler, L. Van Oudenhove, A. M. Gevers, and J. Janssens, "A controlled crossover study of the selective serotonin reuptake inhibitor citalopram in irritable bowel syndrome," Gut, vol. 55, no. 8, pp. 1095-1103, 2006.

[185] U. Ladabaum, A. Sharabidze, T. R. Levin et al., "Citalopram provides little or no benefit in nondepressed patients with irritable bowel syndrome," Clinical Gastroenterology and Hepatology, vol. 8, no. 1, pp. 42-48.e1, 2010.

[186] R. Lewis-Fernandez, P. Lam, S. Lucak et al., “An open-label pilot study of duloxetine in patients with irritable bowel syndrome and comorbid major depressive disorder," Journal of Clinical Psychopharmacology, vol. 36, no. 6, pp. 710-715, 2016.

[187] A. Kaplan, M. D. Franzen, P. V. Nickell, D. Ransom, and P. J. Lebovitz, "An open-label trial of duloxetine in patients with irritable bowel syndrome and comorbid generalized anxiety disorder," International Journal of Psychiatry in Clinical Practice, vol. 18, no. 1, pp. 11-15, 2014.

[188] B. P. Brennan, K. V. Fogarty, J. L. Roberts, K. A. Reynolds, H. G. Pope Jr., and J. I. Hudson, "Duloxetine in the treatment of irritable bowel syndrome: an open-label pilot study," Human Psychopharmacology, vol. 24, no. 5, pp. 423-428, 2009.

[189] J. L. Jackson, J. M. Mancuso, S. Nickoloff, R. Bernstein, and C. Kay, "Tricyclic and tetracyclic antidepressants for the prevention of frequent episodic or chronic tension-type headache in adults: a systematic review and meta-analysis," Journal of General Internal Medicine, vol. 32, no. 12, pp. 1351-1358, 2017.

[190] L. Bendtsen, R. Jensen, and J. Olesen, "A non-selective (amitriptyline), but not a selective (citalopram), serotonin reuptake inhibitor is effective in the prophylactic treatment of chronic tension-type headache," Journal of Neurology, 
Neurosurgery, and Psychiatry, vol. 61, no. 3, pp. 285-290, 1996.

[191] L. Bendtsen, S. Evers, M. Linde, D. D. Mitsikostas, G. Sandrini, and J. Schoenen, "EFNS guideline on the treatment of tension-type headache - report of an EFNS task force," European Journal of Neurology, vol. 17, no. 11, pp. 1318-1325, 2010.

[192] R. Banzi, C. Cusi, C. Randazzo, R. Sterzi, D. Tedesco, and L. Moja, "Selective serotonin reuptake inhibitors (ssris) and serotonin-norepinephrine reuptake inhibitors (snris) for the prevention of tension-type headache in adults," Cochrane Database of Systematic Reviews, vol. 2015, no. 5, article CD011681, 2015.

[193] R. Banzi, C. Cusi, C. Randazzo, R. Sterzi, D. Tedesco, and L. Moja, "Selective serotonin reuptake inhibitors (ssris) and serotonin-norepinephrine reuptake inhibitors (snris) for the prevention of migraine in adults," Cochrane Database of Systematic Reviews, no. 4, article CD002919, 2015.

[194] R. Chou, R. Deyo, J. Friedly et al., "Systemic pharmacologic therapies for low back pain: a systematic review for an american college of physicians clinical practice guideline," Annals of Internal Medicine, vol. 166, no. 7, pp. 480-492, 2017.

[195] D. M. Urquhart, J. L. Hoving, W. W. Assendelft, M. Roland, and M. W. van Tulder, "Antidepressants for non-specific low back pain," Cochrane Database of Systematic Reviews, vol. 2008, no. 1, article CD001703, 2008. 


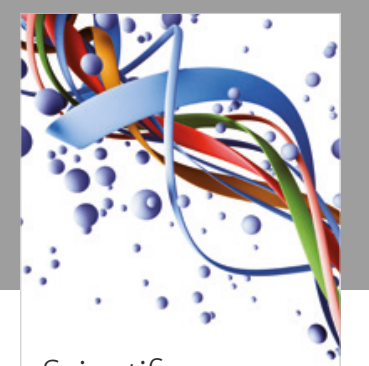

Scientifica
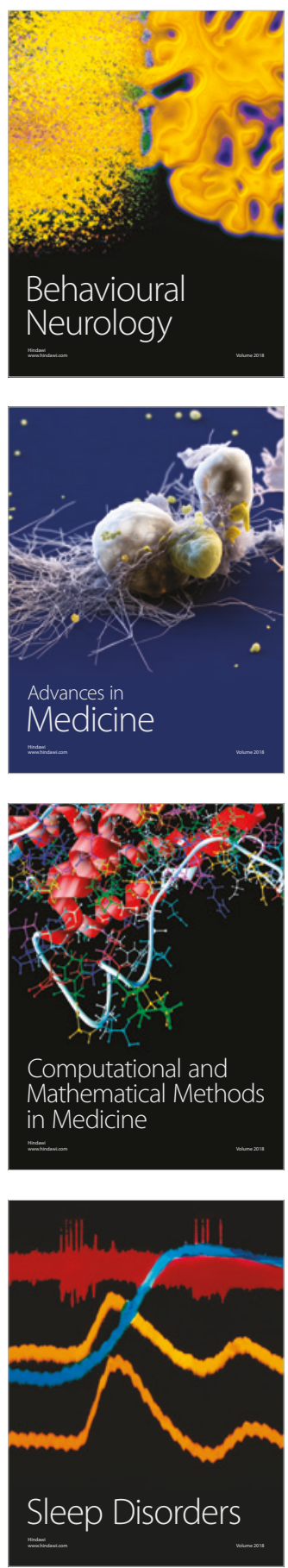

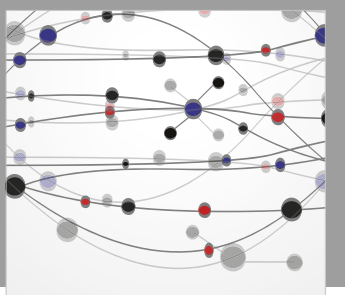

The Scientific World Journal

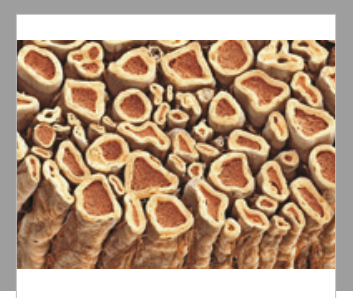

Case Reports in

Neurological Medicine

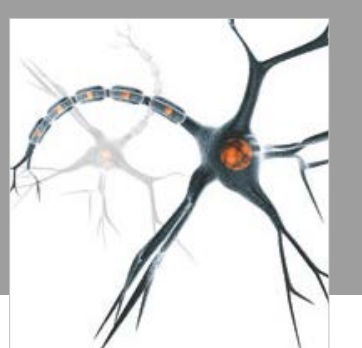

Neural Plasticity

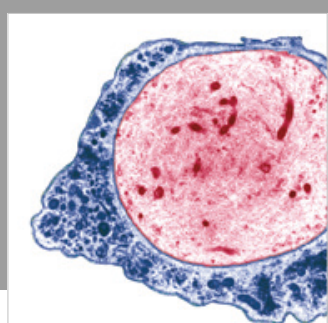

Multiple Sclerosis

International

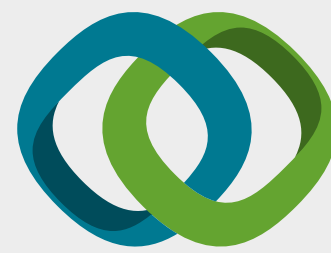

Hindawi

Submit your manuscripts at

www.hindawi.com
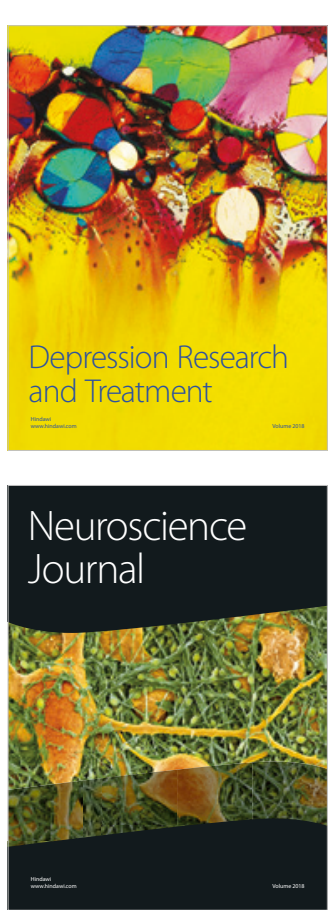

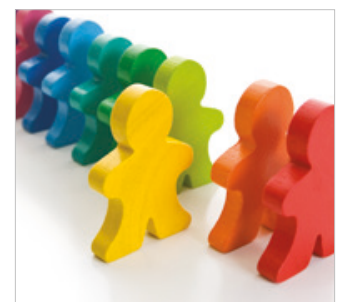

Autism

Research and Treatment
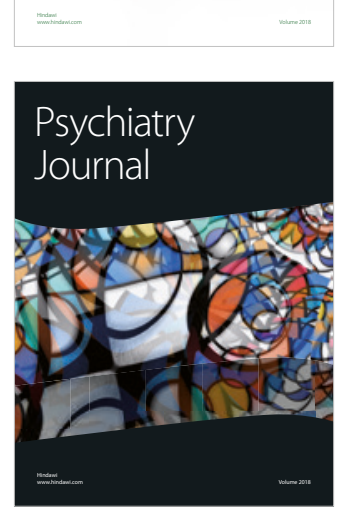
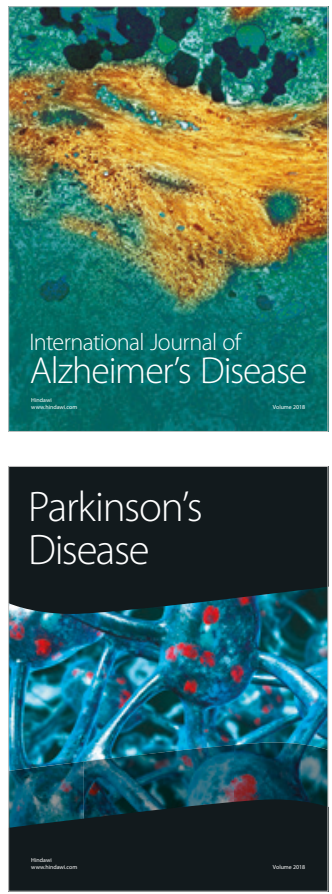
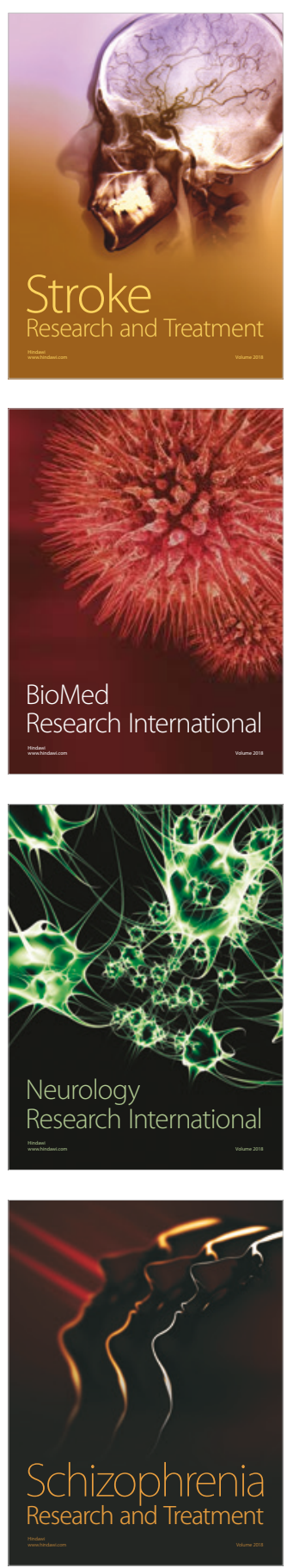